\title{
Effect of IPO Underpricing on Seasoned Offerings*
}

\author{
Chi-Seung Song, Associate Professor, Wonkwang University \\ Jin Q Jeon ${ }^{* *}$, Associate Professor, Dongguk University
}

\begin{abstract}
$\langle$ Abstract $\rangle$
According to IPO signaling theory, IPO underpricing is used under information asymme-try, where an issuing firm has better information on firm quality to signal the firm's true value. This signaling is costly, but may enable the firm to return to the market and sell se-curities on better terms at a later date. The empirical implications of IPO signaling theory is that underpricing has a favorable and significant effect on the probability, size, and speed of subsequent security offerings. This study examines IPO signaling theory using an IPO sample in the KOSDAQ market. We consider the upper or lower price limit in Korea and define underpricing as the first-day return as well as the 10-day and 20-day return after IPOs. We examine the IPO samples in the KOSDAQ market to find that, consistent with the signaling theory, underpricing significantly increases the probability of seasoned securities. This result holds when we estimate the instrumental variable probit model and control for endogeneity. However, we find that the size and period taken for seasoned offerings are not significantly correlated with underpricing. The contribution of this study to the IPO literature is that it is the first study to investigate IPO signaling theory in the Korean market. Furthermore, the finding that underpricing is statistically correlated with the probability of seasoned securities offerings but not statistically correlated with the size and time of such offerings has important academic and practical implications.
\end{abstract}

Keywords: IPO Underpricing; Seasoned Securities Offering; Signaling Effect; Venture Capital; Certification Role

JEL Classification: G24, G30

\footnotetext{
* This study was financially supported by the 2018 KSA-FnGuide research program and 2019 Dongguk University research fund.

** Corresponding Author. Address: 30, Pildong-ro 1-gil, Jung-gu, Seoul, Korea 04020;

E-mail: jjeon@dongguk.edu; Tel: +82-2-2260-8911; Fax: +82-2-2260-3042.
}

Received: March 18, 2019; Revised: May 29, 2019; Accepted: June 27, 2019 


\title{
IPO 저가발행이 이후공모에 미치는 영향*
}

\author{
송 치 승 (원광대학교 부교수) \\ 전 진 규 (동국대학교 부교수)**
}

IPO 저가발행의 원인에 대하여 매우 다양한 이론적 및 실증적 연구가 진행되어 왔다. 이 중 저가발행 신호이론에 따르면 정보비대칭 상황에서 IPO 저가발행은 이 발행기업이 우량기업이라는 신호를 시장에 전달하는 수단이며, 저가발행을 통해 향후 필요 자본을 더 좋은 조건으로 조달할 수 있다. 본 연구는 2000 년부터 2015년까지 코스닥 $\mathrm{IPO}$ 를 대상으로 저가발행과 이후공모와의 관련성을 분석하여 저가발행 신호효과 가설을 검증하였다. 국내 가격제한폭제도를 고려하여 저가발행을 공모가 대비 상장당일 종가수익률과 상장 이후 10 일, 20 일 및 30 일 수익률을 사용하였다. 분석결과 저가발행은 발행기업의 $\mathrm{IPO}$ 이후 주식 또는 채권공모 가능성을 유의하게 높이는 것으로 나타나 신호효과가 국내 IPO 시장에서 존재한다는 것을 증명하였다. 이와 같은 결과는 내생성을 통제한 후 그리고 벤처캐피탈의 인증효과를 통제한 후에도 존재하는 것으로 나타났다. 그러나 저가발행이 이후공모규모와 이후공모까지의 소요 기간에 미치는 영향은 강한 유의성을 보이지 않았다. 본 연구는 국내 연구로는 최초로 저가발행 신호효과에 대하여 실증연구이며, 저가발행이 이후공모 가능성을 높이나 공모규모와 소요기간에는 유의적 영향을 미치지 않는다는 결론은 학문적 및 실무적으로 시사하는 바가 클 것으로 기대한다.

핵심 단어 : IPO 저가발행, 이후공모, 신호효과, 벤처캐피탈, 인증효과

JEL 분류기호: G24, G30

* 본 연구는 2018년 한국증권학회-FnGuide 연구지원사업으로 수행되었으며 FnGuide의 제공 자료를 사용하였습니다.

** 연락담당 저자. 주소: 서울특별시 중구 필동로1길 30 동국대학교 경영대학, 04020;

E-mail: jjeon@dongguk.edu; Tel: 02-2260-8911; Fax: 02-2260-3042. 


\section{1. 서론}

IPO 저가발행은 공모가 대비 상장일 첫날 수익률 또는 우리나라처럼 가격제한폭이 존재 경우는 공모가 대비 공모 후 단기수익률이 유의하게 양의 값을 갖는 현상을 의미한다. 저가발행은 세계 대부분의 시장에서 일반적으로 나타나는 현상인데, 미국의 경우 평균 $10 \%$ 20\%의 IPO 초기수익률이 발생하는 것으로 알려져 있다. 저가발행 현상은 프랑스 및 독일 시장에서는 다소 낮게 나타나고 아시아 및 라틴 아메리카 시장에서는 상대적으로 높게 나타난다(Ljungqvist, 2007). 우리나라의 경우 평균 30\% 대의 저가발행 현상이 나타나며, 일반적으로 활황일수록 높게 나타나는 경향이 있다(Park and Jeon, 2015).

저가발행 현상은 Ibbotson(1975)이 미스터리한 현상으로 규정한 후 그 원인에 대하여 많은 연구가 진행되고 있다. 저가발행의 가장 중요한 원인으로 발행사, 주관사 그리고 투자자 등 시장참여자 간 정보의 불균형을 들 수 있는데, 승자의 저주(Rock, 1986), 공모가의 부분조정 (partial adjustment) 현상(Benveniste and Spindt, 1989), 주관사와 발행사 간 대리인문제 (Baron and Holmström, 1980), 그리고 본 연구의 주요 관심사인 신호효과 등이 이 범주에 포함된다. 이밖에도 손실을 입은 피해자로부터의 소송위험(Lee et al., 1996), 주관사의 시장조성 의무 등 시장 제도적·법적 요인도 저가발행의 원인이 된다. 또한 정보의 폭포(Informational cascades), 감정적(Sentimental) 투자자 등등 행태론적 측면에서도 저가발행의 원인이 설명되고 있다(Ljungqvist et al., 2006 등).

본 연구는 이러한 저가발행 원인 중 저가발행의 신호효과를 국내 시장을 대상으로 검증하는데 목적이 있다. 발행사와 투자자 간 정보의 불균형이 존재하는 상황에서 발행사는 IPO 저가발행을 통하여 기업의 진정한 가치를 투자자에게 신호할 수 있는데 이를 저가발행의 신호효과라고 한다(Welch, 1989). 기업의 진정한 가치가 IPO 이후 투자자에게 인지되므로 미래가치가 높은 우량기업의 저가발행은 투자자로 하여금 높은 수익률을 얻게 할 수 있다. 이에 따라 해당기업에 대한 투자자의 호감이 높아지며 이후공모에서 보다 많은 자금을 보다 좋은 조건으로 조달할 수 있게 된다.1) 한편 이러한 저가발행의 신효효과는 저가발행 비용이 이후공모 시 발생하는 수익보다 작을 때 유의하게 발생한다. 비우량기업은 $\mathrm{IPO}$ 이후 기업의 가치가 시장에 인지되므로, $\mathrm{IPO}$ 를 저가 발행하더라도 투자자들이 높은 수익률을 얻을 가능성이 낮다. 따라서 IPO 저가발행을 통하여 이후공모 시 좋은 조건으로 조달하기가 불가능할 가능성이 높다. 즉 비우량기업의 경우 저가발행 비용이 이후공모 시 발생하는 수익보다 크므로 미래 성장성이 높은 기업을 모방하여 저가발행을 신호로 사용하는데 한계가 있다(Allen and Faulhaber, 1989; Grinblatt and Hwang, 1989). 저가발행 신호이론은 Jegadeesh et al.(1993), Michaely and Shaw(1994), Francis et al.(2010) 등에 의해서 실증적으로 분석되었으나 분석결과는 서로 상이하게 나타났다.

한편, 국내 시장에서 IPO 저가발행 신호효과를 검증한 연구는 아직 없는 실정이다. 이에 본 연구에서는 2000년부터 2015년까지 코스닥 시장 IPO를 대상으로 저가발행 신호효과를

1) 본 고에서는 IPO 이후 3년 동안 동일 발행기업의 주식 또는 채권 공모를 “이후공모”로 정의하였다. 또한 주식공모(유상증자)를 별개로 분류하여 “이후 주식공모”로 정의하였다. 
검증하고자 하였다. 저가발행률은 코스닥 시장의 가격제한폭제도를 고려하여 상장 첫날 수익률, 그리고 상장 이후 10 일, 20 일, 30 일 수익률 등으로 다양하게 정의하였다.2)

먼저 저가발행이 IPO 이후 3 년 동안 주식 또는 채권공모 여부에 미치는 영향을 분석하였다. Logit 모형을 설정하여 추정한 결과 첫날 수익률은 이후공모 여부에 유의하지 않은 반면에 상장 후 10 일 및 20 일 수익률은 유의한 정(+)의 관계를 보였다. 이는 IPO 시 발행사가 저가발행을 함으로써 기업에 대한 투자자의 호감을 제고하여 이후 자본조달을 더욱 수월하게 한다는 가설과 일치하는 결과이다. 한편, 저가발행과 이후공모에 대한 의사결정이 상호의존적으로 이루어지는 경우 두 변수 간 내생적 관계가 존재할 수 있다(Michaely and Shaw, 1994). 이러한 내생성을 통제하기 위하여 IV(instrumental variable) probit 모형을 설정하고 추정한 결과 저가발행과 이후공모 여부 간 정(+)의 관계는 유지되었다. 또한, 이후공모를 시행한 기업은 IPO 시 벤처캐피탈의 투자를 받을 뿐만 아니라 저가발행률도 높이는 경향이 있는 것으로 나타났다. 이는 벤처캐피탈의 인증효과가 저가발행의 신호효과를 대체할 수 있다는 기존 연구와 다른 결과이다.

다음으로 저가발행이 이후공모 발행규모 및 이후공모까지 소요기간에 미치는 영향을 분석 하였다. Heckman 표본선택편의(selection bias) 및 OLS를 추정한 결과 저가발행률과 발행규모 및 소요기간 간의 관계는 유의하지 않게 나타났다. 이는 IPO 저가발행 신호효과와 일치하지 않는 결과이다. 본 연구는 아직 국내에서 수행되지 않았던 IPO 저가발행의 신호효과에 대한 최초의 실증연구라는데 공헌점이 있다. 저가발행이 이후공모 가능성을 높이는데 반하여 이후공모의 규모와 소요기간에는 유의한 영향을 미치지 않는다는 결과는 학문적 또는 실무적으로 시사하는 바가 크다고 할 수 있다.

본 논문의 구성은 다음과 같다. 제 2 장에서는 저가발행 신호효과에 관한 선행연구를 정리하고 이를 토대로 가설을 설정하였다. 제 3장은 데이터 구성 및 연구 모형에 관하여 기술하였다. 제 4장에서는 실증분석 결과를 제시하였으며, 제 5 장에서는 결론을 제시하였다.

\section{2. 선행 연구 및 가설 설정}

\section{$2.1 \mathrm{IPO}$ 저가발행과 신호효과}

$\mathrm{IPO}$ 저가발행(IPO underpricing)은 공모가와 상장일 종가 간 수익률로(최초수익률) 측정 하는데 우리나라처럼 일일 가격제한폭이 있는 경우 3 일 또는 1 주일 등의 단기 수익률을 측정하기도 한다. IPO 저가발행 현상은 우리나라뿐만 아니라 세계적으로도 일반적으로 나타나는 현상이다. 예를 들면 2014년 9월 알리바바(Alibaba)의 경우 공모가가 68달러였으며 상장일 당일 종가는 93.89달러로 38.1\% 수익률을 보였다. J. Ritter 플로리다대학 교수에 의하면 우리나라는 1980년 부터 2013년까지 IPO 평균 최초수익률은 59.3\%이다.3)

2) 본문에서 언급된 초기수익률은 저가발행률과 동일한 개념이다.

3) J. Ritter 교수의 홈페이지(https://site.warrington.ufl.edu/ritter/ipo-data/) 참조. 
한국증권학회지 제48권 5호 (2019)

세계적으로 저평가가 가장 높은 시장은 평균 최초수익률 $264 \%$ 를 보인 사우디아라비아이며 중국도 $118.4 \%$ 의 높은 수익률을 보이고 있다. 미국 시장의 경우 평균 최초수익률은 $16.9 \%$, 일본도 $41.7 \%$ 를 보이는 등 전 세계적으로 $\mathrm{IPO}$ 저가발행은 일반적인 현상이다. 다만 저가발행의 정도는 기간마다 다르게 나타나는데 1999 2001년 인터넷 버블기간 중 극단적으로 높게 나타났으며 2008 2009년 글로벌 금융위기 기간에는 매우 낮게 나타났다. 또한 IPO 저가발행은 선진자본시장보다 신흥시장에서 더 높게 나타나는 경향을 보인다.

IPO 저가발행의 원인을 규명하는 선행연구들을 요약하면 저가발행의 원인을 크게 정보비대칭, 제도적 원인, 기업지배권, 그리고 행동재무적 요인 등으로 구분할 수 있다. 이 중 많은 선행연구들은 발행사, 주관사 그리고 투자자 간 정보비대칭이 저가발행의 주요 원인이라고 하였다(Ljungqvist, 2007). 정보비대칭 관련 선행연구들은 다음과 같다. 먼저 $\operatorname{Rock}(1986)$ 은 정보를 많이 가진 투자자들은 저평가된 우량기업의 공모주만 선별적으로 투자하는 데 반하여, 정보가 부족한 투자자들은 이를 구분할 수 없으므로 상대적으로 우량 공모주 보다는 부실 공모주에 투자할 가능성이 높다고 하였다. 이러한 승자의 저주(winner's curse) 문제로 인하여 정보가 부족한 투자자들은 IPO 시장에 참여를 꺼리게 되는데, 이러한 투자자들을 시장에 유인하기 위하여 공모가격을 할인한 필요가 있다고 주장하였다. 승자의 저주는 투자자간 정보의 이질성에 따라 다르게 나타나는데, Michaely and Shaw(1994)는 이러한 이질성이 낮을수록 승자의 저주 효과는 낮게 나타난다고 하였다.

주관사가 공모가를 결정하기 위하여 사전에 투자자의 수요를 파악하게 되는데 사전시장(premarket)을 열어서 투자자(주로 기관투자자)의 매수의사를 구하는 과정을 거치게 된다. 주관사는 예상수요가 많을 경우에는 공모가를 상향조정하고 예상수요가 적을 경우에는 하향조정하는 방식으로 공모가를 수정한다. 이때 중요한 점은 주관사가 투자자로부터 진실한 정보를 위하여 그 대가를 지불하여야 하는데 이러한 대가의 지불방법으로 예상수요가 많을 경우의 가격 상향조정 폭을 줄여서 그 차액을 보전해주는 경향이 있다. 이를 정보의 부분적 수용가설이라고 한다 (Benveniste and Spindt, 1989). 그러나 사전시장에서 가격협의에 대한 정보가 비공개정보이기 때문에 상기 이론에 대한 실증분석은 매우 제한적일 수밖에 없다. Cornelli and Goldreich (2001, 2003)은 유럽 투자은행들의 실제 IPO 기록을 분석하였는데 그 결과는 대체로 Benveniste and Spindt의 가설과 일치한다.

주관사와 발생사 간 대리인문제와 관련하여 Loughran and Ritter(2003)에 따르면 주관사는 공모가를 최대한 상향하여 발행사의 부를 증진시키기 보다는 자신의 이해를 증진시키는데 더 노력하는 경향이 있다. 주관사의 이해로 특정 투자자에게 더 낮은 가격으로 신주를 배정하고 과도한 수수료를 받는 것, 발행사의 임원에게 낮은 가격으로 신주를 배정하고 미래 인수업무를 배정 받는 것 등이 있다. Biais et al.(2002)도 수요조사 과정에서 주관사와 주요 기관투자자들 간 담합의 가능성을 제기하였는데 이 역시 발행사의 이해에는 부정적인 영향을 미치게 된다. Ljungqvist and Wilhelm(2005)은 발행기업이 주관사의 실사 및 마케팅활동들에 대한 모니터링을 강화하고 공모가산정에 대한 협상에 적극적으로 임하였을 때 이러한 대리인비용을 완화시킬 수 있다고 하였다. Ljungqvist(2003)는 주관사에 대한 보상 등 계약조건이 대리인 비용을 완화시키는 중요 요인이라고 하였다. 
Effect of IPO Underpricing on Seasoned Offerings

이와 같이 정보불균형을 토대로 IPO 저가발행을 설명한 이론 중 본 연구와 관련이 깊은 이론은 저가발행에 대한 신호효과이론이다. 본 신호이론에서는 발행사가 외부투자자에 비해 기업가치에 대하여 더 많은 정보를 보유하고 있다는 가정한다. 이러한 정보의 비대칭 하에서 저가발행은 기업 내재가치에 대한 신호로 사용될 수 있다(Ibbotson, 1975; Welch, 1989). 미래의 내재가치가 높을 것으로 예상되는 기업은 자신의 우월성을 인정받기 위하여 저가발행을 함으로서 정보비대칭을 완화시킬 수 있는데, 미래 내재가치가 낮은 기업은 저가발행의 비용이 매우 크므로 모방하기가 어렵다.4) 또한 미래 내재가치가 높은 기업은 이러한 IPO 저가발행을 통하여 기업에 대한 투자자의 신뢰와 만족을 증대시킨 다음 향후 추가 자본조달을 더욱 수월하게 할 수 있으며 이를 통하여 저가발행으로 인한 손실을 회수할 수 있다(Allen and Faulhaber, 1989; Grinblatt and Hwang, 1989).

한편 발행기업이 자신의 가치에 대하여 시장에 신호를 보내는 도구로 저가발행 뿐만 아니라 명망있는 주관사(Booth and Smith, 1986), 외부회계감사인(Titman and Trueman, 1986), 그리고 벤처캐피탈(Megginson and Weiss, 1991; Lin, 1996; Kim and Jun, 2017 등)로부터의 가치에 대한 인증서비스를 사용할 수도 있다. 이러한 기관들이 인증서비스를 성실히 수행한다면 발행기업 입장에서는 저가발행에 대한 동기가 사라질 수 있다.

이러한 저가발행의 신호효과에 대한 실증분석은 이후공모의 여부, 가격, 공시효과 등이 IPO 저가발행과 양 $(+)$ 의 관계가 있는 지를 분석한다. Jegadeesh et al.(1993)은 유상증자의 여부 및 규모가 IPO 저가발행과 양(+) 관계가 있음을 보였는데 경제적 유의성은 매우 작게 나타났다. 더구나 저가발행 보다 IPO 이후의 수익률이 훨씬 더 유의한 변수임을 보였다. Michaely and Shaw(1994)는 저가발행과 이후공모에 대한 의사결정은 상호의존적으로 이루어진다고 주장 하였고, 이를 검증하기 위하여 동시추정(simultaneous estimation)모형을 추정하였다. 추정결과 저가발생과 이후공모 간 유의한 관계를 발견하지 못하여 Jegadeesh, Weinstein and Welch의 결론과 같이 저가발행 신호이론 대한 실증적 증거를 찾지 못했다. 한편, Francis et al.(2010)은 정보불균형이 높은 분할된 시장에서 저가발행에 의한 IPO 신호효과가 존재함을 보였다.

Welch(1996)는 유상증자까지의 기간에 대한 결정은 내생적으로 결정되며, 내재가치가 높은 기업일수록 자신의 가치가 노출되기를 원하므로 기간이 길어지는 경향이 있다고 하였다. 따라서 $\mathrm{IPO}$ 저가발행과 이후 증자 간 기간은 양(+)의 관계가 있으며, IPO 이후 수익률이 높은 기업은 기간이 짧아지는 경향이 있다. 또한 Jegadeesh et al.(1993)와 Slovin et al.(1994)은 IPO 저가발행이 유상증자 공시 시 주가반응에 긍정적 효과를 미친다고 하였다. 이는 IPO 저가발행의 신호효과와 일치하는 결론이라고 할 수 있다. 한편, 저가발행이 기업가치의 신호로 작용한다면 구주주는 IPO 시 자신의 물량을 매도하지 않고 향후 주가가 상승할 때까지 매도를 지양할 것이다.

4) 신호이론은 우량기업이 열등한 기업보다 저가발행률이 더 높다고 주장하는 것은 아니다. 다만 우량 기업이 저가발행을 하는 동기 중 하나로 이후공모에서의 효익을 제시한다. 
한국증권학회지 제 48 권 5 호 (2019)

\section{2 가설 설정}

본 연구에서는 IPO 저가발행 신호효과에 대한 선행연구들의 논의를 바탕으로 연구가설을 설정한다. IPO 시장의 정보비대칭 하에서 내재가치가 높은 기업은 자신의 우월성을 인정받기 위하여 저가발행을 통해 투자자로 하여금 높은 초기수익률을 얻게 함으로서 기업에 대한 신뢰와 만족을 향상시킬 수 있다(Welch, 1989; Allen and Faulhaber, 1989; Grinblatt and Hwang, 1989). 이는 미래 주식의 가치에 긍정적인 영향을 미치게 되고 발행사는 원활한 추가 자본조달로 부터 저가발행에 의한 비용 보다 높은 효익을 얻을 수 있다. 저가발행 신호효과가 제시하는 실증적 함의는 저가발행이 클수록 이후공모를 쉽게 할 수 있을 뿐만 아니라 더 많은 자본을 수월하게 조달할 수 있다는 것이다. 따라서 저가발행이 높은 발행기업 일수록 이후공모를 실시할 가능성이 높으며, 이후공모를 통해 더 많은 자금을 조달할 것이라는 가설이 성립한다. 다만 $\mathrm{IPO}$ 이후 이후공모까지의 소요기간의 관계는 명확하지 않다. 한편으로는 저가발행을 통해 IPO 이후 필요자본을 더욱 빨리 조달하려한다는 가설이 성립 가능하지만, 다른 한편으로는 내재가치가 높은 기업일수록 자신의 가치가 노출되기를 원하므로 추가 자본조달까지 기간이 길어지는 경향이 있을 수 있다(Welch, 1996). 이는 실증적 검증이 필요한 부분이다.

한편 발행사가 자신의 내재가치를 시장에 보내는 신호의 도구로 저가발행 뿐만 아니라 명성이 높은 주관사와 벤처캐피탈의 인증효과 등이 있다. Carter and Manaster(1990)와 Megginson and Weiss(1991)는 명성이 높은 주관사일수록 충실한 인증서비스를 제공하므로 저가발행을 낮춘다고 하였다. 반면에, 명성이 높은 주관사일수록 IPO에 투자한 고객들의 부를 높이거나 IPO 물량의 빠른 소진을 위하여 오히려 저가발행을 유도할 수 있다는 주장도 제기되었다 (Loughran and Ritter, 2003). 벤처캐피탈이 투자기업에 대해 가치인증과 정보전달 기능을 수행하는 경우 벤처캐피탈은 투자 IPO 벤처기업의 공모가격이 과소하게 설정되는 공모주 저가발행을 낮추는 인증효과를 가질 수 있다. 이러한 벤처캐피탈 인증효과를 발견한 연구로 Megginson and Weiss(1991), Lin(1996), Belghitar and Dixon(2012) 등이 있다. 반면에 벤처캐피탈은 인증역할 보다는 조기업적을 과시(grandstanding)하는 경향이 있음을 주장한 연구도 있다(Lee and Wahal, 2004). 국내연구도 벤처캐피탈의 인증효과에 대한 실증분석 결과가 혼재되어 있는데, Lee et al.(2010), Oh and Han(2014), Song and Lee(2018) 등은 벤처캐피탈의 인증효과가 있음을 보였으나, Jang and Khil(2000), Kim and Park(2013) 등은 인증효과를 발견하지 못하였다.

저가발행 신호이론에 따르면 저가발행 현상은 발행기업은 자신의 가치에 대한 신호를 보내기 위하여 기업의 내재가치를 고의적으로 낮게 책정하게 되는데, 벤처캐피탈이 인증역할을 적절히 수행한다면 발행기업의 고의적인 저가발행 동기는 사라지게 된다. 따라서 벤처캐피탈의 인증 효과를 통제한 후에도 이후공모 가능성에 유의적인 영향을 미치는 지는 실증적으로 검증할 필요가 있다. 또한 저가발행의 원인이 이후공모를 수월하게 하기 위한 동시 의사결정이라면 (Michaely and Shaw, 1994) 저가발행과 이후공모 간 내생적 관계가 있다고 할 수 있으므로 추정식에서 적절한 내생성의 통제가 필요하다. 
Effect of IPO Underpricing on Seasoned Offerings

위와 같은 논의에 근거하여 연구가설을 설정하고 실증분석을 통해 검증한다.

가설 1: $\mathrm{IPO}$ 저가발행이 큰 발행기업일수록 $\mathrm{IPO}$ 이후 주식 또는 채권 공모를 실행할 가능성이 높을 것이다.

가설 2: $\mathrm{PO}$ 저가발행이 큰 발행기업일수록 $\mathrm{IPO}$ 이후공모까지의 기간이 짧고 이후공모 규모가 클 것이다.

가설 3: 위의 가설 1 과 가설 2 와 같은 $\mathrm{IPO}$ 저가발행의 신호효과는 벤처캐피탈의 인증역할이 고려될 경우 나타나지 않을 것이다.

\section{3. 연구 자료, 분석 모형 및 단순통계량}

\section{1 연구 자료}

본 연구에 사용된 자료는 2000년 1월부터 2015년 12월 기간 동안 코스닥에 상장한 IPO 기업 중에서 재무제표가 구비된 기업을 대상으로 금융업종, 지주회사 출범에 의한 재상장 및 분할상장기업, 스펙상장, 그리고 중국계 상장기업은 제외한다. 이에 해당하는 코스닥 IPO 870건에 대한 정보는 금융감독원 전자공시시스템(DART, http://dart.fss.or.kr/)에서 개별 추출하였다. 신규 공모기업의 저가발행에 관한 선행연구에서 해외연구는 대부분이 상장 첫날 수익률(공모가 대비 상장 첫날 종가의 수익률)을 사용하고 있는 반면 국내 주식시장은 가격제한폭제도(2015년 까지 $\pm 15 \%$, 이후 $\pm 30 \%$ )를 운용하고 있어 상장 첫날 수익률로 초기수익률 측정 시 과소평가될 우려가 있다. 따라서 본 연구에서는 상장 첫날 수익률, 그리고 상장 10 일, 20 일 및 30 일 동안 수익률을 초기수익률로 사용하였다.5)

한편 벤처캐피탈의 인증효과를 검증하기 위해 본 연구에서는 전통적 캐피탈과 기업벤처 캐피탈이 실제로 투자한 기업을 벤처기업으로 정의하였다. 미국 시장에서 벤처기업은 벤처 캐피탈이 투자한 기업으로 정의하지만, 국내 시장에서는 일반적으로 벤처특별법으로 지정된 기업을 벤처기업으로 정의한다.6) 그러나 벤처캐피탈이 실제 투자하지 않았음에도 불구하고

5) IPO 관련 국내 연구들에서는 가격제한폭 제도(2015년까지 $\pm 15 \%$, 이후 $\pm 30 \%$ )를 감안하여 IPO 저가발행을 상장 첫날 수익률뿐만 아니라 다양한 단기간 수익률을 사용하였다. Lim et al.(2016)은 첫날 수익률과 더불어 상장 후 3일 또는 5일 수익률을 사용하였으며, Byun and Cho(2011)도 IPO 저평가현상 측정을 위해 상장당일 수익률과 5 일, 10 일, 15 일, 20 일 및 25 일 수익률을 사용하였다. $\mathrm{Lee}(2015)$ 는 공모주 발행가격 대비 상장 이후 21일 종가수익률을 상장초기수익률로 정의하였다.

6) 전통적 벤처캐피탈이란 재무적 목적의 투자자로서 한국에서는 창업투자회사와 신기술금융회사를 일컫는다. 이에 비해 일반기업이 자체의 자본금을 가지고 창업이나 초기 단계에 있는 기업에 투자를 하는 경우를 기업벤처캐피탈이라고 칭한다. 한편, 벤처특별법 제 2 조 2 항에 벤처기업에 대한 정의로 (1) 벤처투자기업: 벤처투자기관(창투사 및 신기술금융회사, 산업은행, 기업은행 등)으로부터 투자받은 금액이 자본금의 $10 \%$ 이상이고 5,000만 원 이상인 기업, (2) 연구개발기업: 기업부설연구소 보유기업 으로서 연간 연구개발비가 5천만 원 이상이고 연구개발비가 매출액의 $5 \% \sim 10 \%$ 이상인 기업, (3) 기술평가보증·대출기업: 기술보증기금의 보증 또는 중소기업진흥공단의 대출을 받은 기업으로 보증. 대출금액이 8 천만 원 이상이고 총자산의 $5 \%$ 이상인 기업 등이 벤처기업으로 분류되고 있다. 
한국증권학회지 제48권 5호 (2019)

벤처특별법에서 정의된 연구기업 등은 벤처캐피탈의 인증과 관련이 없으므로 본 연구에는 벤처캐피탈이 투자한 기업을 벤처기업으로 정의하였다.

이후공모 또는 이후 주식공모 여부, 공모 규모 및 이후공모까지 소요기간 등 자료는 금융감독원 전자공시시스템에서 개별 추출하였다. 또한 재무 및 주가자료는 에프엔가이드(FnGuide)에서 제공하는 DataGuide에서 획득하였다.

\section{〈표 1〉코스닥 IPO 연도별 분포 및 저가발행률}

Panel 1은 본 연구에 사용된 2000년부터 2015년 말까지 기간 동안 코스닥 시장에 기업공개 된 IPO 및 벤처캐피탈 지원에 대한 연도별 분포이다. Panel 2 는 전체표본과 상장 첫날 수익률 크기의 순서대로 구성된 4 개의 집단(FR1 $\rightarrow \mathrm{FR} 4)$ 을 대상으로 저가발행률에 대한 측정치인 첫날 수익률, 그리고 상장 10 일, 20 일 및 30 일 동안 수익률의 분포를 보여준다.

Panel 1: 코스닥 IPO 연도별 분포

\begin{tabular}{ccc}
\hline 연도 & 코스닥시장 IPO 수 & 벤처캐피탈 지원 IPO \\
\hline 2000 & 94 & 38 \\
2001 & 95 & 55 \\
2002 & 93 & 40 \\
2003 & 46 & 30 \\
2004 & 38 & 25 \\
2005 & 51 & 29 \\
2006 & 42 & 31 \\
2007 & 58 & 37 \\
2008 & 30 & 25 \\
2009 & 49 & 34 \\
2010 & 48 & 29 \\
2011 & 52 & 33 \\
2012 & 20 & 19 \\
2013 & 33 & 24 \\
2014 & 56 & 47 \\
2015 & 65 & 55 \\
\hline 합계 & 870 & 551 \\
\hline
\end{tabular}

Panel 2: 저가발행률 분포

\begin{tabular}{lllcccc}
\hline \multirow{2}{*}{ 저가발행률 } & \multirow{2}{*}{ 전체표본 } & \multicolumn{4}{c}{ 첫날 수익률 크기 순서에 따른 IPO 집단 } \\
\cline { 3 - 6 } & & FR1 & FR2 & FR3 & FR4 \\
\hline 첫날 수익률 & 평균 & 0.4632 & 1.3026 & 0.4013 & 0.1912 & -0.0513 \\
& 중앙값 & 0.3375 & 1.0000 & 0.3029 & 0.1268 & -0.0429 \\
상장 10일 & 평균 & 0.4329 & 1.1818 & 0.4265 & 0.2018 & -0.0818 \\
& 중앙값 & 0.3096 & 1.0560 & 0.3740 & 0.1520 & -0.1033 \\
상장 20일 & 평균 & 0.4120 & 1.0819 & 0.4271 & 0.2215 & -0.0858 \\
& 중앙값 & 0.2939 & 0.9777 & 0.3640 & 0.1171 & -0.0831 \\
상장 30일 & 평균 & 0.4102 & 1.0589 & 0.4456 & 0.2047 & -0.0716 \\
& 중앙값 & 0.3063 & 0.9391 & 0.3792 & 0.1358 & -0.0802 \\
\hline
\end{tabular}


Effect of IPO Underpricing on Seasoned Offerings

<표 1>의 Panel 1은 본 연구에 사용된 표본으로 2000년 이후 코스닥 시장에 기업공개 된 870건의 $\mathrm{IPO}$ 에 대한 연도별 분포이다. 또한 벤처캐피탈의 인증효과를 고려하기 위하여 벤처 캐피탈의 지원을 통하여 공개된 IPO를 분리하였다. 총 870건의 IPO 중 551건(63.33\%)이 벤처캐피탈의 지원에 의하여 상장되었음을 보여준다. 벤처캐피탈 지원 $\mathrm{IPO}$ 는 전통적 벤처캐피탈과 기업벤처캐피탈의 지원에 의하여 상장된 $\mathrm{IPO}$ 이다. Panel 2는 저가발행률 측정치인 첫날 수익률과 상장 후 10 일, 20 일 및 30 일 동안 수익률을 보여준다. 전체표본에서 첫날 수익률의 평균은 $46.32 \%$ 로 상장 10 일(평균 43.29\%), 20일(평균 41.2\%) 및 30일(평균 41.02\%) 동안 수익률보다 높게 나타난다. 이는 기타 상장 이후 단기간 수익률에 비해 저가발행이 첫날 수익률에 충분히 반영된다고 볼 수 있다. 그러나 첫날 수익률 크기 순서대로 구성된 4 개의 IPO 집단(FR1 FR4)의 저가발행률 측정치를 보면, 위와 같은 현상은 첫날 수익률이 매우 높은 FR1 집단과 매우 낮은 FR4 집단에서 유의하게 발생됨을 알 수 있다. 즉 첫날 수익률이 중간수준인 FR2와 FR3 집단에서는 첫날 수익률보다 상장 10 일과 상장 20 일(또는 상장 30 일)의 수익률이 더 높다. 이는 가격제한폭제도를 고려할 때 첫날 수익률 뿐만 아니라 상장 이후 단기간 수익률도 저가발행율의 측정치로 사용할 수 있다는 점을 시사한다.

\section{〈표 2〉코스닥 IPO 이후 3년간 SPO 현황}

아래 표는 본 연구에 사용된 2000년부터 2015년 말까지 기간 동안 코스닥 시장에 기업공개 된 IPO 중 $\mathrm{IPO} 3$ 년간 $\mathrm{SPO}$ 현황이다. 채권 및 주식 공모 여부와 $\mathrm{IPO}$ 당시 벤처캐피탈 지원여부 $(\mathrm{VC}=1)$ 를 구분하였다.

\begin{tabular}{|c|c|c|c|c|c|c|}
\hline \multirow{2}{*}{ 횟수 } & \multicolumn{2}{|c|}{ 채권 } & \multicolumn{2}{|c|}{ 주식 } & \multicolumn{2}{|c|}{ 채권 \& 주식 } \\
\hline & \multicolumn{2}{|c|}{$\mathrm{VC}=1$} & \multicolumn{2}{|c|}{$\mathrm{VC}=1$} & \multicolumn{2}{|c|}{$\mathrm{VC}=1$} \\
\hline 1 & 16 & 11 & 117 & 61 & 20 & 15 \\
\hline 2 & 10 & 8 & 12 & 9 & 9 & 8 \\
\hline 3 & 6 & 6 & 6 & 3 & 2 & 2 \\
\hline 4 & 3 & 3 & 1 & 1 & 2 & 2 \\
\hline 5 & 1 & 1 & & & 1 & 1 \\
\hline 6 & & & & & & \\
\hline 7 & 2 & 1 & & & & \\
\hline 8 & & & & & & \\
\hline 9 & & & & & & \\
\hline 10 & 1 & 1 & & & & \\
\hline 합계 & 39 & 31 & 136 & 74 & 34 & 28 \\
\hline
\end{tabular}

<표 2>는 2000년부터 2015년 코스닥시장에 기업공개 된 IPO 중 상장 후 3년 동안 채권 혹은 주식을 공모한 기업들의 수이다. 39개 기업들은 IPO 이후 한 번 이상 채권을 공모 하였으며, 136 개 기업들은 한 번 이상 주식을 공모하였다. 또한 34 개 기업들은 한 번 이상 채권과 주식을 동시에 공모하였다. 또한 채권 공모의 경우 벤처캐피탈 지원을 받은 IPO는 31 건(79.49\%), 주식 공모의 경우 74 건(54.41\%), 주식과 채권을 동시에 공모하는 경우 28 건(82.35\%)이 벤처캐피탈 지원을 받았다. 


\section{2 분석 모형}

먼저 초기수익률이 이후공모에 미치는 영향을 분석하기 위하여 다음과 같은 logit 모형을 추정한다.

$$
\begin{aligned}
& S P O_{i}^{*}=\alpha+\beta \text {. 저가발행률 }{ }_{i}+\Gamma X_{i}+e_{i} \\
& \text { 여기서, } S P O_{i}=\left\{\begin{array}{l}
1 \text { if } S P O_{-} d_{i}^{*}>0 \\
0 \text { if } S P O_{i}^{*}<0
\end{array}\right.
\end{aligned}
$$

여기서 $S P O$ 는 IPO 이후 3 년 이내 주식 또는 채권 공모가 있을 경우 1 의 값을 갖으며, 그렇지 않을 경우 0 의 값을 갖는 더미변수이다. 또한 이후공모 중 주식공모가 발생했을 경우 1 의 값을 갖는 SPO_Stock 변수도 추가로 고려하였다. 저가발행률의 측정치로 상장 첫날 수익률, 그리고 상장 후 10 일과 20 일 수익률을 사용하였으며, 부가적으로 상장 후 30 일 수익률을 사용하였다.

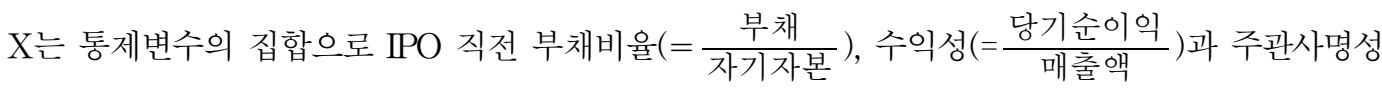
(매년 인수업무 수주 기준 상위 5 위 이내일 경우 1 , 아니면 0$)$, 발행규모 $(=\operatorname{Ln}($ 총발행액 $)$ 그리고 업종더미변수를 포함한다.7)

한편, Michaely and Shaw(1994)은 저가발행률이 큰 기업은 IPO 후 이후공모 가능성이 낮으며, 저가발행률이 낮은 기업은 기업공개 이후 수익성과 배당가능성이 높음을 발견하였다. 즉, 이후공모에 시행 계획이 공모가 산정에 대한 의사결정 시 반영된다는 것이다. 이과 같은 결과는 저가발행과 이후공모 간 내생적 관계가 존재함을 시사한다. 이와 같은 내생성을 통제하기 위하여 다음과 같은 2 단계 IV probit(instrumental variable probit) 모형을 추정한다(Wooldridge, 2002).8)

1단계: 저가발행률 ${ }_{i}=\alpha+\gamma Z+\Gamma X+u_{i}$

2단계: $S P O_{i}^{*}=\alpha+\beta$ ·저가발행률 ${ }_{i}+\Gamma X_{i}+q \hat{u}_{i}+e_{i}$

$$
\text { 여기서, } S P O_{i}=\left\{\begin{array}{l}
1 \text { if } S P O_{i}^{*}>0 \\
0 \text { if } S P O_{i}^{*}<0
\end{array}\right.
$$

7) 통제변수 중 기업규모변수는 발행규모와 상관관계가 매우 높아(0.75) 다중공선성 문제가 발생할 수 있으므로 회귀식에서 제외하였다. 다중공선성 추정치인 분산팽창계수(VIF, variance inflation factor)는 logit 등 비선형회귀모형에서는 정의되지 않으므로 선형회귀모형을 가정한 다중공선성 진단결과, $\ln$ (총자산)을 제외한 다른 통제변수들의 다중공선성 문제는 나타나지 않았다. 다만, 기업규모를 나타내는 $\ln$ (총자산)의 Tolerance는 0.0585 이며 $\operatorname{VIF}(=1 /$ Tolerance)는 17.11 로 나타나 다중공선성 문제가 있음을 알 수 있었다.

8) IV probit 모형이 일반적인 $2 \mathrm{SLS}(2$ stage least squared) 모형과 다른 점은 1단계 회귀식에서 구한 종속변수의 예측치를 2 단계 본 식에 사용하지 않고 잔차를 사용한다는 점인데 그 이유는 본 식인 2단계 회귀식이 비선형이기 때문이다. 
Effect of IPO Underpricing on Seasoned Offerings

여기서 $Z$ 는 도구변수의 집합이다. 도구변수는 1 단계 종속변수인 초기수익률과는 유의한 관계가 있고 2 단계 종속변수인 이후공모 여부와는 유의한 관계가 없어야하는 요건이 필요하다. 이에 따라 도구변수로 동종업계의 평균 초기수익률과 같은 해에 발생한 IPO의 평균 초기수익률을 사용하였다.9) X는 식 (1)에서 제시된 통제변수의 집합이다.

저가발행 신호이론에 따라 설정한 본 연구의 가설 2에 의하면 초기수익률은 이후공모여부에 영향을 미칠 뿐만 아니라 이후공모의 규모에 정(+)의 영향을 이후공모까지 소요기간에 부(-)의 영향을 미친다. 여기서 이후공모 규모와 이후공모까지의 소요기간은 이후공모를 시행하였을 때만 관찰되는 절단변수들(truncated variables)이다. 한편 Michaely and Shaw(1994)에 따르면 이후공모 시행여부가 저가발행에 대한 의사결정과 동시에 결정될 수 있으므로 이후공모를 실시한 발행사의 표본은 무작위가 아닐 수 있다. 만약 이후공모 시행 표본이 무작이가 아니라면, 단순 OLS을 사용할 경우 추정 편의가 존재하게 된다. 이와 같은 내생성을 고려하여 Heckman 표본선택 편의(selection bias)모형을 추정한다(Heckman, 1976, 1979).

$$
\begin{aligned}
& 1^{\text {st }} \text { step : } S P O^{*}=\alpha+\beta \text {.초기수익률 }{ }_{i}+\Gamma X_{i}+\delta z+u_{i} \\
& \text { 여기서, } S P O_{i}=\left\{\begin{array}{l}
1 \text { if } S P O_{i}^{*}>0 \\
0 \text { if } S P O_{i}^{*}<0
\end{array}\right. \\
& 2^{\text {nd }} \text { step : SPO_proceeds }(\text { or period })=\alpha+\beta \text {.초기수익률 }{ }_{i}+\Gamma X_{i}+\rho \hat{\lambda}+e_{i}
\end{aligned}
$$

여기서 SPO_proceeds는 이후공모(또는 이후 주식공모) 발행규모의 자연로그 값이다. $S P O \_$periods는 $\mathrm{IPO}$ 에서 이후공모(또는 이후 주식공모)까지 소요된 개월 수의 자연로그 값이다. 이다. X는 식 (1)에서 제시된 통제변수의 집합니다. $\hat{\lambda}$ 는 $1^{\text {st }}$ step에서 추정한 Inverse of Mill's Ratio로

$$
\hat{\lambda}=\frac{\phi\left(\alpha+\beta \cdot \text { 초기수익률 }_{i}+\Gamma X_{i}+\delta z+u_{i}\right)}{\Phi\left(\alpha+\beta \cdot \text { 초기수익률 }_{i}+\Gamma X_{i}+\delta z+u_{i}\right)}
$$

로 정의된다. $1^{\text {st }}$ step 프로빗모형은 모든 관찰치를 포함하며, $2^{\text {nd }}$ step의 OLS 회귀분석은 이후공모(혹은 이후주식공모)가 발생한 표본만을 이용하여 추정한다. 위 식에서 $\rho$ 값이 통계적으로 유의할 경우 단순 OLS 사용 시 추정 편의가 존재함을 의미한다. 만약 $\rho$ 값이 통계적으로 유의하지 않다면 OLS와 Heckman 표본선택편의 모형의 추정결과는 같다.

\section{3 기술적 통계}

$<$ 표 3>은 IPO 이후공모여부에 따라 분류한 기업군의 상장직전 주요 재무현황을 보여준다. Panel 1은 채권과 주식을 포함한 이후공모여부를 분류한 결과이며 Panel 2는 주식 공모만을

9) 회귀분석 결과 도구변수들은 요건에 충족하는 것으로 나타났는데 본 논문에서는 도구변수 요건에 대한 검증 결과는 지면제약으로 인해 보고하지 않았다. 
고려하여 분류한 결과이다. Panel 1에서 IPO 이후공모를 하지 않은 기업군(SPO=0)이 이후 공모를 시행한 기업군 $(\mathrm{SPO}=1)$ 보다 기업규모와 수익성이 유의하게 높음을 알 수 있다. Panel 2 도 비슷한 결과를 보여주는데, 부채규모를 제외하고 유상증자를 하지 않은 기업들의 규모와 수익성이 유의하게 높다. 즉 이후공모가 없는 집단은 높은 수익성과 규모로 인해 자본의 내부조달 능력이 더 높다고 할 수 있다. 또한 규모와 수익성이 상대적으로 낮은 이후공모 시행 기업들은 도입기 또는 성장기 기업으로 생각될 수 있다. 이러한 기업들은 미래 투자처가 상대적으로 많고 내부유보금이 낮으므로 회사채나 주식발행에 의한 외부조달을 시행할 가능성이 높다. 이와 같은 해석은 Panel 2에도 적용된다. 즉 기업 규모와 수익성이 상대적으로 낮은 기업은 외부조달 중 주식발행에 의한 자금조달을 이용할 가능성이 높다.

\section{〈표 3〉이후공모여부별 IPO 기업의 재무현황}

아래 표는 본 연구에 사용된 코스닥 IPO 표본에서 이후공모를 시행한 집단( $\mathrm{SPO}=1)$ 과 하지 않은 집단(SPO =0) 간 주요 재무변수를 비교하였다. Panel 2는 이후공모 중 주식공모(SPO_Stock)만을 분리하여 분석하였다. 이상치에 의한 영향을 고려하기 위하여, 각각 $3 \%$ 와 $97 \%$ 에서 winsorizing 하였다. ${ }^{* * *},{ }^{* *}$ 그리고 *은 각각 $1 \%, 5 \%$ 그리고 $10 \%$ 유의수준에서 통계적으로 유의함을 나타낸다.

Panel 1: 전체 표본

(단위: 억 원)

\begin{tabular}{|c|c|c|c|c|c|}
\hline \multicolumn{2}{|c|}{ 변수 } & $\mathrm{SPO}=0$ & $\mathrm{SPO}=1$ & t-test & Wilcoxon test \\
\hline \multirow{3}{*}{ 매출액 } & 평균 & 404.3 & 334.9 & \multirow{3}{*}{$2.32^{* *}$} & \multirow{3}{*}{$-2.58^{* * *}$} \\
\hline & 표준편차 & 348.6 & 307.7 & & \\
\hline & 중앙값 & 278.6 & 246.3 & & \\
\hline \multirow{3}{*}{ 순이익 } & 평균 & 45.1 & 34.7 & \multirow{3}{*}{$3.67^{* * *}$} & \multirow{3}{*}{$-4.19^{* * *}$} \\
\hline & 표준편차 & 35.5 & 31.4 & & \\
\hline & 중앙값 & 34.1 & 25.5 & & \\
\hline \multirow{3}{*}{ 영업이익 } & 평균 & 56.2 & 43.0 & \multirow{3}{*}{$3.66^{* * *}$} & \multirow{3}{*}{$-4.02^{* * *}$} \\
\hline & 표준편차 & 46.2 & 39.5 & & \\
\hline & 중앙값 & 41.6 & 31.5 & & \\
\hline \multirow{3}{*}{$\begin{array}{l}\text { 영업활동 } \\
\text { 현금흐름 }\end{array}$} & 평균 & 46.9 & 31.0 & \multirow{3}{*}{$3.73^{* * *}$} & \multirow{3}{*}{$-4.40^{* * *}$} \\
\hline & 표준편차 & 53.8 & 47.2 & & \\
\hline & 중앙값 & 33.0 & 19.6 & & \\
\hline \multirow{3}{*}{ 총자산 } & 평균 & 344.9 & 286.3 & \multirow{3}{*}{$2.53^{* *}$} & \multirow{3}{*}{$-3.25^{* * *}$} \\
\hline & 표준편차 & 286.8 & 257.4 & & \\
\hline & 중앙값 & 251.1 & 195.5 & & \\
\hline \multirow{3}{*}{ 부채 } & 평균 & 153.1 & 144.8 & \multirow{3}{*}{0.59} & \multirow{3}{*}{-0.90} \\
\hline & 표준편차 & 163.1 & 161.5 & & \\
\hline & 중앙값 & 99.4 & 89.9 & & \\
\hline \multirow{3}{*}{ 자기자본 } & 평균 & 190.3 & 143.2 & \multirow{3}{*}{$4.05^{* * *}$} & \multirow{3}{*}{$-4.66^{* * *}$} \\
\hline & 표준편차 & 153.7 & 126.1 & & \\
\hline & 중앙값 & 144.1 & 104.0 & & \\
\hline \multicolumn{2}{|l|}{ 관찰치 } & 626 & 164 & & \\
\hline
\end{tabular}


Effect of IPO Underpricing on Seasoned Offerings

〈표 3〉이후공모여부별 IPO 기업의 재무현황(계속)

Panel 2: 주식공모 표본

(단위: 억 원)

\begin{tabular}{|c|c|c|c|c|c|}
\hline \multicolumn{2}{|c|}{ 변수 } & SPO_Stock $=0$ & SPO_Stock $=1$ & t-test & Wilcoxon test \\
\hline \multirow{3}{*}{ 매출액 } & & 406.7 & 323.7 & \multirow{3}{*}{$3.02^{* * *}$} & \multirow{3}{*}{$-3.00^{* * *}$} \\
\hline & 표준편차 & 349.7 & 299.1 & & \\
\hline & 중앙값 & 279.1 & 238.4 & & \\
\hline \multirow{3}{*}{ 순이익 } & 평균 & 45.1 & 34.3 & \multirow{3}{*}{$3.76^{* * *}$} & \multirow{3}{*}{$-4.43^{* * *}$} \\
\hline & 표준편차 & 35.4 & 31.6 & & \\
\hline & 중앙값 & 34.1 & 24.2 & & \\
\hline \multirow{3}{*}{ 영업이익 } & 평균 & 56.3 & 42.5 & \multirow{3}{*}{$3.79^{* * * *}$} & \multirow{3}{*}{$-4.29^{* * *}$} \\
\hline & 표준편차 & 46.1 & 39.7 & & \\
\hline & 중앙값 & 41.8 & 30.4 & & \\
\hline \multirow{3}{*}{$\begin{array}{l}\text { 영업활동 } \\
\text { 현금흐름 }\end{array}$} & 평균 & 46.9 & 30.9 & \multirow{3}{*}{$3.72^{* * *}$} & \multirow{3}{*}{$-4.39^{* * *}$} \\
\hline & 표준편차 & 53.8 & 47.1 & & \\
\hline & 중앙값 & 33.0 & 19.6 & & \\
\hline \multirow{3}{*}{ 총자산 } & 평균 & 346.6 & 278.2 & \multirow{3}{*}{$2.97^{* * *}$} & \multirow{3}{*}{$-3.66^{* * *}$} \\
\hline & 표준편차 & 287.4 & 252.2 & & \\
\hline & 중앙값 & 252.7 & 285.3 & & \\
\hline \multirow{3}{*}{ 부채 } & 평균 & 154.8 & 138.1 & \multirow{3}{*}{1.16} & \multirow{3}{*}{-1.40} \\
\hline & 표준편차 & 164.8 & 153.9 & & \\
\hline & 중앙값 & 99.9 & 88.4 & & \\
\hline \multirow{3}{*}{ 자기자본 } & 평균 & 190.3 & 141.9 & \multirow{3}{*}{$4.12^{* * *}$} & \multirow{3}{*}{$-4.91^{* * *}$} \\
\hline & 표준편차 & 153.3 & 127.1 & & \\
\hline & 중앙값 & 144.5 & 102.6 & & \\
\hline 관찰치 & & 631 & 160 & & \\
\hline
\end{tabular}

\section{4. 실증분석 결과}

\section{1 저가발행과 이후공모}

<표 4>는 IPO 저가발행과 이후공모 여부와의 관계를 나타낸 단일변량분석 결과이다. Panel 1 은 채권과 주식을 포함한 이후공모여부, Panel 2 는 주식 공모만을 고려하여 분류한 결과이다. 코스닥 시장은 일일 가격상한제가 존재하므로 IPO 초기수익률을 계산하기 위하여 공모가와 상장일 종가 수익률뿐만 아니라 상장 후 10 일, 20 일, 그리고 30 일 수익률을 사용하였다. Panel 1 에서 $\mathrm{SPO}=1$ 기업군의 초기수익률은 상장 $\mathrm{SPO}=0$ 기업군의 초기수익률 보다 당일 수익률을 제외하고 모든 경우에서 유의하게 높게 나타났다. 주식공모여부로 분류한 Panel 2의 결과도 위와 비슷하게 나타났다. 이와 같은 단일변량분석의 결과는 저가발행이 신호로 작용하여 이후 공모를 보다 수월하게 한다는 가설과 일치한다. 다만 본 결과는 이후공모여부에 영향을 미치는 다른 중요 변수들을 고려하지 않았으므로 다중회귀분석에서 이러한 변수들을 통제한 후 저가발행과 이후공모 간 관계를 추정하였다. 
한국증권학회지 제 48 권 5 호 (2019)

〈표 4〉 저가발행과 이후공모 여부-단일변량분석

아래 표는 본 연구에 사용된 코스닥 IPO 표본에서 이후공모를 시행한 집단(SPO =1)과 하지 않은 집단(SPO =0) 간 주요 수익률을 비교하였다. Panel 2는 이후공모 중 주식공모(SPO_Stock)만을 분리하여 분석하였다. $\mathrm{IPO}$ 초기수익률(또는 저가발행률)은 상장 첫날 수익률 및 상장이후 10 일, 20 일, 그리고 30 일 동안 수익률을 사용하였다. ${ }^{* * *}{ }^{* *}$ 그리고 ${ }^{*}$ 은 각각 $1 \%, 5 \%$ 그리고 $10 \%$ 유의수준에서 통계적으로 유의함을 나타낸다.

Panel 1: 전체 표본

\begin{tabular}{|c|c|c|c|c|c|c|}
\hline \multirow{2}{*}{ 저가발행률 } & \multicolumn{2}{|c|}{$\mathrm{SPO}=0$} & \multicolumn{2}{|c|}{$\mathrm{SPO}=1$} & \multirow{2}{*}{ t-test } & \multirow{2}{*}{ Wilcoxon } \\
\hline & 평균 & 중앙값 & 평균 & 중앙값 & & \\
\hline 첫날 수익률 & 0.4498 & 0.3223 & 0.5137 & 0.4561 & -1.44 & $1.99^{* *}$ \\
\hline 상장 10일 & 0.4060 & 0.2859 & 0.5403 & 0.4580 & $-2.32^{* *}$ & $2.63^{* * *}$ \\
\hline 상장 20일 & 0.3850 & 0.2597 & 0.5195 & 0.4203 & $-2.36^{* *}$ & $2.86^{* * *}$ \\
\hline 상장 30일 & 0.3827 & 0.2714 & 0.5196 & 0.4634 & $-2.57^{* *}$ & $2.95^{* * *}$ \\
\hline
\end{tabular}

Panel 2: 주식공모 표본

\begin{tabular}{|c|c|c|c|c|c|c|}
\hline \multirow{2}{*}{ 저가발행률 } & \multicolumn{2}{|c|}{ SPO_Stock $=0$} & \multicolumn{2}{|c|}{ SPO_Stock = 1} & \multirow{2}{*}{ t-test } & \multirow{2}{*}{ Wilcoxon } \\
\hline & 평균 & 중앙값 & 평균 & 중앙값 & & \\
\hline 첫날 수익률 & 0.4519 & 0.3248 & 0.5069 & 0.4495 & -1.24 & $1.79^{*}$ \\
\hline 상장 10일 & 0.4080 & 0.2878 & 0.5353 & 0.4293 & $-2.18^{* *}$ & $2.49^{* *}$ \\
\hline 상장 20일 & 0.3869 & 0.2610 & 0.5153 & 0.4171 & $-2.23^{*}$ & $2.72^{* * *}$ \\
\hline 상장 30일 & 0.3838 & 0.2784 & 0.5187 & 0.4633 & $-2.51^{* *}$ & $2.87^{* * *}$ \\
\hline
\end{tabular}

<표 5>는 IPO 저가발행이 이후공모 여부에 미치는 영향을 분석한 logit 모형의 추정결과이다. 초기수익률 변수로 먼저 해외문헌에서 일반적으로 사용되는 공모가 대비 상장일 종가 수익률을 사용하였으며, 국내 시장의 가격제한폭제도를 고려하여 상장 후 10 일 및 20 일 수익률을 사용 하였다. Panel 1은 IPO 이후 3년 이내 발생한 이후공모를 대상으로, Panel 2 또는 Panel 3은 각각 $\mathrm{IPO}$ 이후 2 년 또는 1 년 이내 발생한 이후공모를 대상으로 분석하였다. 먼저 상장첫날 수익률은 이후공모 여부 또는 이후 주식공모 여부와 유의한 관계가 없는 것으로 나타났다. 가격제한폭제도를 고려하여 초기수익률을 상장 후 10 일과 20 일 수익률로 정의하였을 때 초기 수익률은 이후공모 여부에 $10 \%$ 유의수준에서 유의한 정(+)의 영향을 미치는 것으로 나타났다. 또한 초기수익률은 이후 주식공모 가능성도 유의하게 높이는 것으로 나타났다. 이는 IPO 기업이 저가발행을 자신의 내재가치에 대한 신호로 사용하여 향후 추가 공모를 수월하게 할 수 있을 것이라는 가설 1 과 일치한다. 모든 회귀식에서 기업의 레버리지가 높을수록 이후공모 가능성이 높아지는 것으로 나타났는데, 부채가 많은 기업일수록 부채수용력(debt capacity)의 한계로 인하여 추가 공모 필요성이 높기 때문이다(Yoon, 2016). IPO 발행규모가 큰 기업은 향후 자금조달 필요성이 크지 않으므로 이후공모 여부와 유의한 부(-)의 값을 갖는 것으로 나타났다.

<표 6>은 저가발행과 이후공모 여부 간 내생적 관계를 통제하기 위하여 IV probit 모형을 추정한 결과이다.10) 분석결과는 logit 모형을 추정하였던 <표 $5>$ 와 비슷하게 나타났다. 상장 첫날 수익률은 이후공모 여부에 유의한 영향을 미치지 못하였는데 이는 가격제한폭제도로

10) IV probit 분석결과는 지면제약 상 1 단계 회귀식 추정결과는 생략하였다. 
Effect of IPO Underpricing on Seasoned Offerings

〈표 5〉 저가발행과 이후공모 여부-logit 회귀분석

아래 표는 저가발행률이 이후공모 여부에 미치는 영향을 분석한 logit 회귀분석 결과이다. IPO 초기수익률 (또는 저가발행률)은 상장 첫날 수익률과 상장이후 10 일 및 20 일 동안 수익률을 사용하였다. 레버리지는 IPO 시 부채/자기자본, 수익성은 당기순이익/매출액이며, 주관사 명성은 주관사가 해당 년도 실적 상위 5 위 내 있을 경우 1 의 값을 갖는다. $\operatorname{Ln}$ (발행규모)는 총 발행규모(gross proceeds)의 로그값이다. 표준오차는 robust standard errors를 사용하였으며, [ ] 안 숫자는 t 또는 $Z$ 값을 나타낸다. ${ }^{* * *}$, ${ }^{* *}$ 그리고 *은 각각 $1 \%, 5 \%$ 그리고 $10 \%$ 유의수준에서 통계적으로 유의함을 나타낸다.

Panel 1: IPO 이후 3년 이내 발생한 이후공모 분석

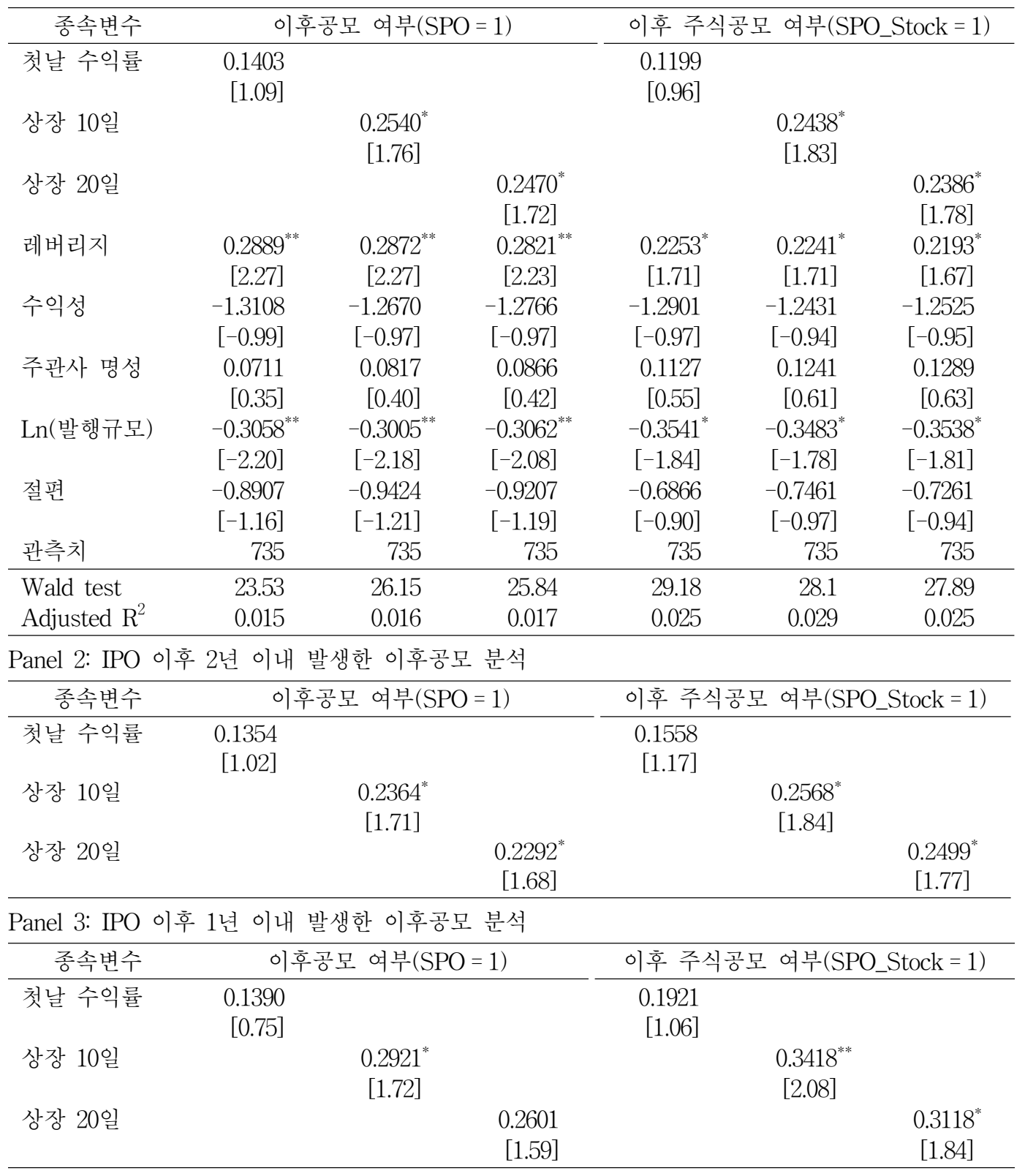


한국증권학회지 제48권 5호 (2019)

인해 IPO 저가발행률이 저평가되었기 때문으로 사료된다. 저가발행 측정기간을 10 일 또는 20 일로 하였을 때 저가발행은 이후공모 여부와 이후 주식공모 여부에 유의한 영향을 미치는 것으로 나타났으며 이는 가설 1 에 일치한 결과이다. 통제변수 중 레버리지는 이후공모 가능성을 유의하게 높이며, IPO 발행규모는 유의하게 낮추는 것으로 나타났다. Wald test for exogeneity는 내생성 존재 여부에 대한 검증 결과로써, III.2의 IV probit 분석모형에 대한 설명 중 1 단계 회귀식으로 추정한 잔차를 2 단계 회귀식에 추가시켰을 때 그 회귀계수의 유의성을 나타낸다. 분석 결과 첫날 수익률 변수에는 내생성이 없는 것으로 나타났으며, 상장 10 일 및 상장 20 일 변수에는 내생성이 존재하는 것으로 나타났다.

〈표 6〉저가발행과 이후공모 여부-IV probit 분석

아래 표는 저가발행률이 이후공모 여부에 미치는 영향을 분석하기 위하여 IV probit(instrumental variable probit) 모형으로 내생성을 통제한 결과이다. IPO 초기수익률(또는 저가발행률)은 상장 첫날 수익률과 상장이후 10 일 및 20 일 동안 수익률을 사용하였다. 레버리지는 IPO 시 부채/자기자본, 수익성은 당기순이익/ 매출액이며, 주관사 명성은 주관사가 해당 년도 실적 상위 5 위 내 있을 경우 1 의 값을 갖는다. $\operatorname{Ln}($ 발행규모)는 총 발행규모(gross proceeds)의 로그값이다. 표준오차는 robust standard errors를 사용하였으며, [ ]안 숫자는 $\mathrm{t}$ 또는 $\mathrm{z}$ 값을 나타낸다. ${ }^{* * *}$, ${ }^{* *}$ 그리고 ${ }^{*}$ 은 각각 $1 \%, 5 \%$ 그리고 $10 \%$ 유의수준에서 통계적으로 유의함을 나타낸다.

\begin{tabular}{|c|c|c|c|c|c|c|}
\hline 종속변수 & \multicolumn{3}{|c|}{ 이후공모 여부(SPO = 1) } & \multicolumn{3}{|c|}{ 이후 주식공모 여부(SPO_Stock=1) } \\
\hline 첫날 수익률 & $\begin{array}{c}0.2216 \\
{[0.69]}\end{array}$ & & & $\begin{array}{r}0.1730 \\
{[0.53]}\end{array}$ & & \\
\hline 상장 10 일 & & $\begin{array}{l}0.5056^{* *} \\
{[2.15]}\end{array}$ & & & $\begin{array}{l}0.5403^{* *} \\
{[2.31]}\end{array}$ & \\
\hline 상장 20일 & & & $\begin{array}{c}0.4825^{*} \\
{[1.93]}\end{array}$ & & & $\begin{array}{l}0.5177^{* *} \\
{[2.41]}\end{array}$ \\
\hline 레버리지 & $\begin{array}{c}0.1768^{* *} \\
{[2.27]}\end{array}$ & $\begin{array}{l}0.1694^{* *} \\
{[2.20]}\end{array}$ & $\begin{array}{l}0.1612^{* * *} \\
{[2.05]}\end{array}$ & $\begin{array}{c}0.1375^{*} \\
{[1.73]}\end{array}$ & $\begin{array}{c}0.1316^{*} \\
{[1.69]}\end{array}$ & $\begin{array}{c}0.1227^{*} \\
{[1.78]}\end{array}$ \\
\hline 수익성 & $\begin{array}{c}-0.7149 \\
{[-1.00]}\end{array}$ & $\begin{array}{c}-0.6053 \\
{[-0.88]}\end{array}$ & $\begin{array}{c}-0.6203 \\
{[-0.89]}\end{array}$ & $\begin{array}{l}-0.7060 \\
{[-0.98]}\end{array}$ & $\begin{array}{c}-0.5667 \\
{[-0.82]}\end{array}$ & $\begin{array}{c}-0.5824 \\
{[-0.90]}\end{array}$ \\
\hline 주관사 명성 & $\begin{array}{c}0.0512 \\
{[0.44]}\end{array}$ & $\begin{array}{c}0.0664 \\
{[0.58]}\end{array}$ & $\begin{array}{c}0.0764 \\
{[0.67]}\end{array}$ & $\begin{array}{c}0.0729 \\
{[0.63]}\end{array}$ & $\begin{array}{c}0.0896 \\
{[0.79]}\end{array}$ & $\begin{array}{c}0.1003 \\
{[0.69]}\end{array}$ \\
\hline Ln(발행규모) & $\begin{array}{c}-0.1576^{*} \\
{[-1.94]}\end{array}$ & $\begin{array}{l}-0.1245^{* *} \\
{[-2.07]}\end{array}$ & $\begin{array}{l}-0.1377^{* *} \\
{[-2.18]}\end{array}$ & $\begin{array}{c}-0.1892^{*} \\
{[-1.69]}\end{array}$ & $\begin{array}{c}-0.1445^{*} \\
{[-1.72]}\end{array}$ & $\begin{array}{c}-0.1587^{*} \\
{[-1.72]}\end{array}$ \\
\hline 절편 & $\begin{array}{r}-0.6735 \\
{[-1.40]}\end{array}$ & $\begin{array}{l}-0.8653^{* *} \\
{[-2.00]}\end{array}$ & $\begin{array}{c}-0.8179^{*} \\
{[-1.82]}\end{array}$ & $\begin{array}{l}-0.5295 \\
{[-1.10]}\end{array}$ & $\begin{array}{c}-0.7894^{*} \\
{[-1.83]}\end{array}$ & $-0.7406^{*}$ \\
\hline 관측치 & 735 & 735 & 735 & 735 & 735 & 735 \\
\hline Wald test & $22.69^{* * *}$ & $31.07^{* * *}$ & $29.53^{* * *}$ & $21.68^{* * *}$ & $27.97^{* * *}$ & $26.41^{* * *}$ \\
\hline Wald test for exogeneity & 1.53 & $2.43^{* *}$ & $1.99^{*}$ & 1.25 & $2.75^{* *}$ & $1.81^{*}$ \\
\hline
\end{tabular}

\section{2 벤처캐피탈, 저가발행과 이후공모}

발행기업이 자신의 가치에 대하여 투자자에게 신호를 보내는 도구로 저가발행 뿐만 아니라 주관사의 명성, 외부회계감사인 그리고 벤처캐피탈로부터의 인증효과가 있다(Titman and 
Effect of IPO Underpricing on Seasoned Offerings

Trueman, 1986; Megginson and Weiss, 1991 등). 이를 감안하여 이번 절에서는 벤처캐피탈의 인증효과가 저가발행의 신호효과에 어떠한 영향을 분석해보고자 한다.

〈표 7〉벤처캐피탈, 저가발행과 이후공모 여부-단일변량분석

아래 표는 본 연구에 사용된 코스닥 $\mathrm{IPO}$ 표본에서 이후공모를 시행한 집단 $(\mathrm{SPO}=1)$ 과 하지 않은 집단(SPO $=0)$ 을 벤처캐피탈 지원여부 $(\mathrm{VC}=0 \mathrm{vs} . \mathrm{VC}=1)$ 로 세부분류한 후 초기수익률을 비교하였다. Panel 2 는 이후공모 중 주식공모(SPO_Stock)만을 분리하여 분석하였다. IPO 초기수익률(또는 저가발행률)은 상장 첫날 수익률과 상장이후 10 일, 20 일 및 30 일 동안 수익률을 사용하였다. ${ }^{* * *}{ }^{* *}$ 그리고 ${ }^{*}$ 은 각각 $1 \%$, $5 \%$ 그리고 10\% 유의수준에서 통계적으로 유의함을 나타낸다.

Panel 1: 전체 표본

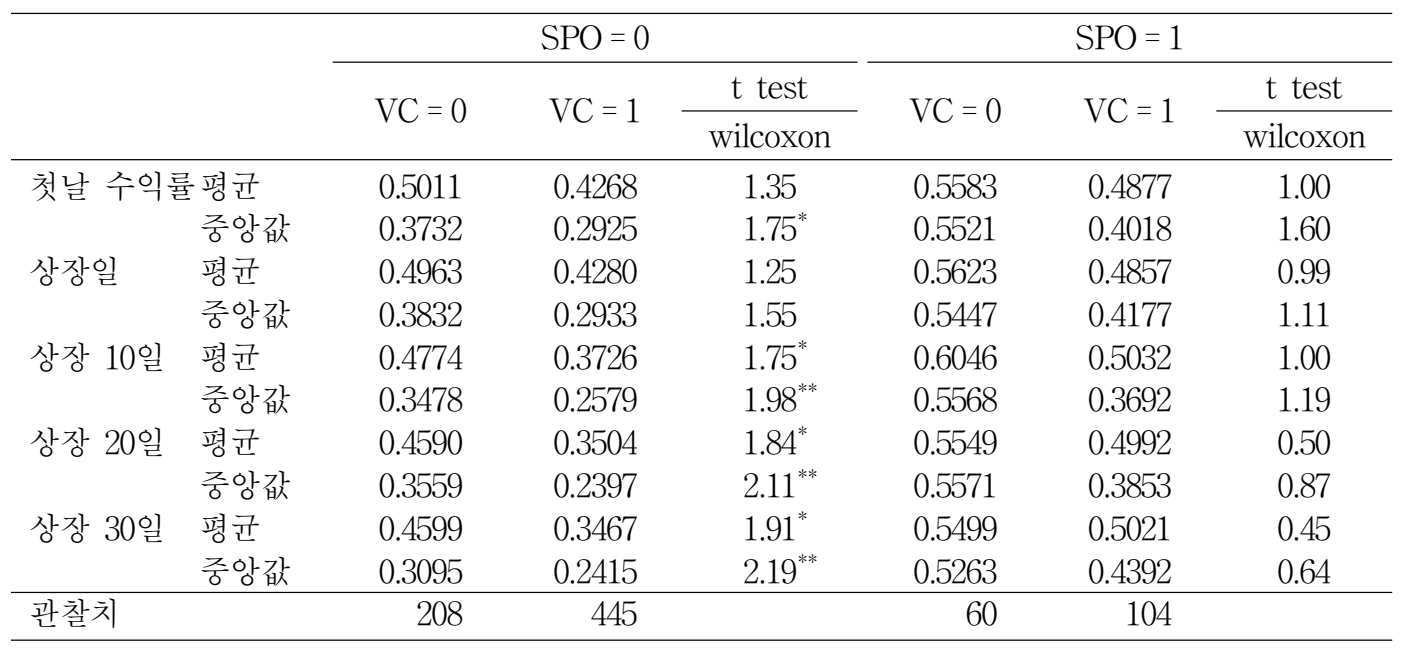

Panel 2: 주식공모 표본

\begin{tabular}{|c|c|c|c|c|c|c|c|}
\hline & & \multicolumn{3}{|c|}{ SPO_Stock $=0$} & \multicolumn{3}{|c|}{ SPO_Stock = 1} \\
\hline & & \multirow{2}{*}{$\mathrm{VC}=0$} & \multirow{2}{*}{$\mathrm{VC}=1$} & \multirow{2}{*}{$\begin{array}{c}\mathrm{t} \text { test } \\
\text { wilcoxon }\end{array}$} & \multirow{2}{*}{$\mathrm{VC}=0$} & \multirow{2}{*}{$\mathrm{VC}=1$} & $\mathrm{t}$ test \\
\hline & & & & & & & wilcoxon \\
\hline \multicolumn{2}{|c|}{ 첫날 수익률평균 } & 0.5011 & 0.4268 & 1.35 & 0.5431 & 0.4855 & 0.74 \\
\hline & 중앙값 & 0.3732 & 0.2925 & $1.75^{*}$ & 0.5338 & 0.4018 & 0.81 \\
\hline \multirow[t]{2}{*}{ 상장일 } & 평균 & 0.4963 & 0.4280 & 1.25 & 0.5480 & 0.4836 & 0.83 \\
\hline & 중앙값 & 0.3832 & 0.2933 & 1.55 & 0.5350 & 0.4177 & 0.93 \\
\hline \multirow[t]{2}{*}{ 상장 10일 } & 평균 & 0.4774 & 0.3726 & $1.75^{*}$ & 0.5980 & 0.4996 & 0.96 \\
\hline & 중앙값 & 0.3478 & 0.2579 & $1.98^{* *}$ & 0.5568 & 0.3692 & 1.09 \\
\hline \multirow[t]{2}{*}{ 상장 20일 } & 평균 & 0.4590 & 0.3504 & $1.84^{*}$ & 0.5478 & 0.4968 & 0.52 \\
\hline & 중앙값 & 0.3559 & 0.2397 & $2.11^{* *}$ & 0.5571 & 0.3853 & 0.79 \\
\hline \multirow[t]{2}{*}{ 상장 30일 } & 평균 & 0.4599 & 0.3467 & $1.91^{*}$ & 0.5518 & 0.4999 & 0.53 \\
\hline & 중앙값 & 0.3095 & 0.2415 & $2.19^{* *}$ & 0.5263 & 0.4392 & 0.64 \\
\hline 관찰치 & & 208 & 445 & & 58 & 102 & \\
\hline
\end{tabular}

<표 6>은 IPO 저가발행률을 이후공모여부와 벤처지원여부로 세부 분류하여 차이를 검증 하였다. 먼저 V.1에서 보고된 바와 같이 이후공모를 시행한 기업의 저가발행률이 그렇지 않은 
한국증권학회지 제 48 권 5 호 (2019)

기업보다 높게 나타났다. 이를 벤처지원여부에 따라 세부 분류하면, 이후공모를 시행한 기업과 시행하지 않은 기업 모두 벤처지원 시 저가발행이 낮게 나타난 것을 알 수 있다. 이는 정보비대칭 하에서 벤처캐피탈의 인증효과로 인하여 저가발행의 정도가 낮아진다는 Oh and $\operatorname{Han}(2014)$, Megginson and Weiss(1991) 등 선행연구 결과와 일치한다.

그러나 이후공모를 시행한 기업군만을 보면 통계적으로 유의하지는 않지만 벤처캐피탈의 투자를 받지 않은 기업의 저가발행률이 낮게 나타났다. 이는 벤처캐피탈 투자 기업의 경우 벤처캐피탈의 인증서비스로 인하여 이후공모를 위한 저가발행의 필요성이 높지 않음을 시사한다. 즉 벤처캐피탈의 인증서비스와 저가발행은 대체재의 관계가 있다. 다만 <표 $6>$ 은 단일변량을 비교한 것이므로, 이후공모에 영향을 미치는 주요 요인들을 통제한 후 저가발행의 신호효과를 검증할 필요가 있다.

$<$ 표 8>은 벤처캐피탈의 지원여부에 따라 저가발행이 이후공모여부에 미치는 영향을 분석한 결과이다. Panel 1과 Panel 3은 각각 이후공모 여부와 이후 주식공모 여부를 종속변수로 하여 $\operatorname{logit}$ 모형을 추정하였으며, Panel 2와 Panel 3은 내생성을 통제한 IV probit 모형의 2단계 회귀식 추정결과이다.11) Panel 1에서 벤처캐피탈 투자를 받은 $\mathrm{IPO}$ 의 경우 상장 후 20 일 수익률이 유의수준 $10 \%$ 에서 유의한 양의 값을 갖는 것으로 나타났으며 그 이외의 초기수익률 관련변수들은 유의하지 않았다. Panel 3 또한 대부분 변수들이 유의하지 않았으며 벤처투자자를 받은 IPO의 상장 후 10 일 및 20 일 수익률이 $10 \%$ 유의수준에서 유의하게 나타났다.

〈표 8〉벤처캐피탈, 저가발행과 이후공모 여부-회귀분석

아래 표는 본 연구에 사용된 코스닥 IPO 표본에서 이후공모를 시행한 집단( $\mathrm{SPO}=1)$ 과 하지 않은 집단(SPO $=0)$ 을 벤처캐피탈 지원여부( $\mathrm{VC}=0 \mathrm{VS} . \mathrm{VC}=1)$ 로 세부분류한 후 초기수익률을 비교하였다. Panel 3 과 Panel 4는 이후공모 중 주식공모(SPO_Stock)만을 분리하여 분석하였다. IPO 초기수익률(또는 저가 발행률)은 상장 첫날 수익률과 상장 이후 10 일 및 20 일 동안 수익률을 사용하였다. 각 Panel에서 통제변수에 대한 회귀계수의 추정치는 <표 6>과 비슷하므로 지면제약 상 생략하였다. 표준오차는 robust standard errors를 사용하였으며, [ ] 안 숫자는 $\mathrm{t}$ 또는 $\mathrm{z}$ 값을 나타낸다. ${ }^{* * *},{ }^{* *}$ 그리고 ${ }^{*}$ 은 각각 $1 \%, 5 \%$ 그리고 $10 \%$ 유의수준에서 통계적으로 유의함을 나타낸다.

Panel 1: 전체 표본-logit 분석

\begin{tabular}{lcccccc}
\hline \multirow{2}{*}{ 종속변수 } & \multicolumn{5}{c}{ 이후공모 여부 $(\mathrm{SPO}=1)$} \\
\cline { 2 - 7 } & $\mathrm{VC}=0$ & $\mathrm{VC}=1$ & $\mathrm{VC}=0$ & $\mathrm{VC}=1$ & $\mathrm{VC}=0$ & $\mathrm{VC}=1$ \\
\hline 첫날 수익률 & 0.1537 & 0.1526 & & & & \\
& {$[0.73]$} & {$[0.92]$} & & & & \\
상장 10일 & & & 0.2341 & 0.2870 & & \\
& & {$[1.06]$} & {$[1.58]$} & & \\
상장 20일 & & & & 0.1967 & $0.3055^{*}$ \\
& & & & & {$[0.93]$} & {$[1.70]$} \\
\hline
\end{tabular}

11) 통제변수로 레버리지, 수익성, 주관사명성, 발행규모 및 업종더미 등을 사용하였는데 지면제약으로 저가발행률 변수의 회귀계수 추정결과만 보고하였다. 
Effect of IPO Underpricing on Seasoned Offerings

〈표 8〉벤처캐피탈, 저가발행과 이후공모 여부-회귀분석(계속)

Panel 2: 전체 표본-IV probit 분석

\begin{tabular}{|c|c|c|c|c|c|c|}
\hline \multirow{2}{*}{ 종속변수 } & \multicolumn{6}{|c|}{ 이후공모 여부(SPO = 1) } \\
\hline & $\mathrm{VC}=0$ & $\mathrm{VC}=1$ & $\mathrm{VC}=0$ & $\mathrm{VC}=1$ & $\mathrm{VC}=0$ & $\mathrm{VC}=1$ \\
\hline 첫날 수익률 & $\begin{array}{c}0.0571 \\
{[0.10]}\end{array}$ & $\begin{array}{r}0.3688 \\
{[0.95]}\end{array}$ & & & & \\
\hline 상장 10일 & & & $\begin{array}{r}0.3385 \\
{[0.94]}\end{array}$ & $\begin{array}{c}0.6028^{* *} \\
{[2.10]}\end{array}$ & & \\
\hline 상장 20일 & & & & & $\begin{array}{r}0.3095 \\
{[0.86]}\end{array}$ & $\begin{array}{c}0.5879^{* *} \\
{[1.98]}\end{array}$ \\
\hline
\end{tabular}

Panel 3: 주식공모 표본- $\operatorname{logit}$ 분석

\begin{tabular}{|c|c|c|c|c|c|c|}
\hline \multirow{2}{*}{ 종속변수 } & \multicolumn{6}{|c|}{ 이후 주식공모 여부(SPO_Stock=1) } \\
\hline & $\mathrm{VC}=0$ & $\mathrm{VC}=1$ & $\mathrm{VC}=0$ & $\mathrm{VC}=1$ & $\mathrm{VC}=0$ & $\mathrm{VC}=1$ \\
\hline 첫날 수익률 & $\begin{array}{c}0.1063 \\
{[0.53]}\end{array}$ & $\begin{array}{r}0.1523 \\
{[0.91]}\end{array}$ & & & & \\
\hline 상장 10일 & & & $\begin{array}{r}0.2177 \\
{[1.02]}\end{array}$ & $\begin{array}{c}0.2868^{*} \\
{[1.78]}\end{array}$ & & \\
\hline 상장 20일 & & & & & $\begin{array}{r}0.1784 \\
{[0.87]} \\
\end{array}$ & $\begin{array}{r}0.3085^{*} \\
{[1.80]} \\
\end{array}$ \\
\hline \multicolumn{7}{|c|}{ Panel 4: 주식공모 표본-IV probit 분석 } \\
\hline \multirow{2}{*}{ 종속변수 } & \multicolumn{6}{|c|}{ 이후 주식공모 여부(SPO_Stock=1) } \\
\hline & $\mathrm{VC}=0$ & $\mathrm{VC}=1$ & $\mathrm{VC}=0$ & $\mathrm{VC}=1$ & $\mathrm{VC}=0$ & $\mathrm{VC}=1$ \\
\hline 첫날 수익률 & $\begin{array}{l}0.0355 \\
{[0.60]}\end{array}$ & $\begin{array}{r}0.3110 \\
{[0.79]}\end{array}$ & & & & \\
\hline 상장 10 일 & & & $\begin{array}{r}0.3954 \\
{[1.11]}\end{array}$ & $\begin{array}{c}0.6192^{* *} \\
{[1.97]}\end{array}$ & & \\
\hline 상장 20일 & & & & & $\begin{array}{r}0.3668 \\
{[1.03]}\end{array}$ & $\begin{array}{c}0.6033^{*} \\
{[1.84]}\end{array}$ \\
\hline
\end{tabular}

그러나 내생성을 통제한 Panel 2 와 Panel 3 을 보면 상장 후 10 일과 20일 수익률의 유의성이 더욱 강하게 나타났다. 벤처캐피탈 지원을 받은 IPO의 경우 저가발행이 높을수록 이후공모의 가능성이 높음을 알 수 있다. 즉 이후공모를 계획한 기업의 경우 IPO 시 벤처캐피탈의 인증과 더불어 저가발행으로 인한 신호효과를 모두 이용하는 경향이 있다는 결과로 해석될 수 있다. 이는 벤처캐피탈의 인증서비스와 저가발행이 상호 보완재임을 시사한다.

\section{3 저가발행과 이후공모 규모 및 소요시간}

저가발행 신호효과 가설에 의하면 저가발행은 기업에 대한 투자자의 호감을 제고하여 이후공모 가능성을 높일 뿐만 아니라 이후공모 규모를 확대하고 소요시간을 단축시킬 수 있다. 본 절에서는 이와 같은 가설 2 를 검증하고자 한다. 
한국증권학회지 제 48 권 5 호 (2019)

<표 9>의 Panel 1은 이후공모 또는 이후 주식공모 시 발행규모와 소요기간에 대한 단순 통계량이다. 벤처캐피탈 투자를 받은 IPO의 경우 향후 공모 시 더 큰 금액을 조달하며, 소요기간도

〈표 9〉 저가발행과 이후공모 규모 및 소요기간

Panel 1은 이후공모 또는 이후 주식공모 시 발행규모와 IPO로부터 소요기간의 평균과 중앙값을 보여준다. 복수의 이후공모가 실시된 경우 IPO 이후 가장 먼저 발생한 이후공모를 기준으로 분석하였다. Panel 2 는 전체표본을 대상으로 저가발행이 이후공모 규모 및 소요기간에 미치는 영향을 분석한 Heckman 표본선택 편의 모형의 추정결과이며, Panel 3은 이후공모를 실행한 기업만을 대상으로 분석한 OLS 추정결과이다. Panel 4와 Panel 5는 이후 주식공모를 시행한 기업만을 대상으로 하였다. 종속변수인 이후공모(또는 이후주식공모) 발행규모의 자연로그 값이며, 이후공모까지 기간은 IPO에서 이후공모(또는 이후주식공모)까지 소요된 개월 수의 자연로그 값이다. IPO 초기수익률(또는 저가발행률)은 상장 첫날 수익률과 상장이후 10 일 및 20일 동안 수익률을 사용하였다. Panel 3과 Panel 5의 통제변수의 회귀계수 추정값은 생략하였다. 표준오차는 robust standard errors를 사용하였으며, [ ]안 숫자는 t 또는 $z$ 값을 나타낸다. ${ }^{* * *}{ }^{* *}$ 그리고 ${ }^{*}$ 은 각각 $1 \%, 5 \%$ 그리고 $10 \%$ 유의수준에서 통계적으로 유의함을 나타낸다.

Panel 1: 단순통계량

\begin{tabular}{llrrrrrrr}
\hline & & \multicolumn{3}{c}{ 이후공모 } & & \multicolumn{3}{c}{ 이후주식공모 } \\
\cline { 3 - 4 } \cline { 6 - 8 } & & \multicolumn{3}{c}{$\mathrm{VC}=0$} & $\mathrm{VC}=1$ & & \multicolumn{3}{c}{$\mathrm{VC=0}$} & $\mathrm{VC}=1$ \\
\hline 발행규모 & 평균 & 3,608 & 2,952 & 4,032 & & 3,683 & 3,008 & 4,119 \\
(백만원) & 중앙값 & 84 & 41 & 100 & & 84 & 41 & 100 \\
소요기간 & 평균 & 19.84 & 21.3 & 19.27 & & 19.84 & 20.72 & 19.3 \\
(월) & 중앙값 & 21 & 22 & 19 & & 21 & 22 & 19 \\
\hline
\end{tabular}

Panel 2: Heckman 표본선택편의 모형 추정결과-전체표본

\begin{tabular}{|c|c|c|c|c|c|c|}
\hline & \multicolumn{3}{|c|}{ 이후공모 규모 } & \multicolumn{3}{|c|}{ 이후공모까지 기간 } \\
\hline 첫날 수익률 & $\begin{array}{r}1.1603 \\
{[1.46]}\end{array}$ & & & $\begin{array}{r}-0.1033 \\
{[-0.80]}\end{array}$ & & \\
\hline 상장 10일 & & $\begin{array}{r}0.9805 \\
{[1.20]}\end{array}$ & & & $\begin{array}{c}-2.0230^{*} \\
{[-1.67]}\end{array}$ & \\
\hline 상장 20일 & & & $\begin{array}{r}1.0256 \\
{[1.33]}\end{array}$ & & & $\begin{array}{r}-1.9825 \\
{[-1.54]}\end{array}$ \\
\hline 레버리지 & $\begin{array}{r}0.0722 \\
{[0.11]}\end{array}$ & $\begin{array}{r}0.1702 \\
{[0.10]}\end{array}$ & $\begin{array}{r}0.2742 \\
{[0.12]}\end{array}$ & $\begin{array}{c}-0.2677^{* *} \\
{[-2.41]}\end{array}$ & $\begin{array}{c}-0.2557^{* *} \\
{[-2.49]}\end{array}$ & $\begin{array}{c}-0.1877^{* *} \\
{[-2.36]}\end{array}$ \\
\hline 수익성 & $\begin{array}{r}1.8307 \\
{[0.38]}\end{array}$ & $\begin{array}{r}1.7367 \\
{[0.36]}\end{array}$ & $\begin{array}{r}1.7787 \\
{[0.36]}\end{array}$ & $\begin{array}{r}0.8406 \\
{[0.76]}\end{array}$ & $\begin{array}{r}0.7086 \\
{[0.77]}\end{array}$ & $\begin{array}{r}0.5926 \\
{[0.78]}\end{array}$ \\
\hline 주관사 명성 & $\begin{array}{c}0.5275 \\
{[0.70]}\end{array}$ & $\begin{array}{r}0.3835 \\
{[0.70]}\end{array}$ & $\begin{array}{c}0.5415 \\
{[0.70]}\end{array}$ & $\begin{array}{r}-0.1384 \\
{[-0.82]}\end{array}$ & $\begin{array}{r}0.0496 \\
{[-0.81]}\end{array}$ & $\begin{array}{r}0.2196 \\
{[-0.81]}\end{array}$ \\
\hline Ln(발행규모) & $\begin{array}{c}1.2719^{* * *} \\
{[2.93]}\end{array}$ & $\begin{array}{c}1.2999^{* * *} \\
{[2.95]}\end{array}$ & $\begin{array}{c}1.2319^{* * *} \\
{[2.93]}\end{array}$ & $\begin{array}{c}-0.1968^{* *} \\
{[-2.41]}\end{array}$ & $\begin{array}{c}-0.2688^{* *} \\
{[-2.22]}\end{array}$ & $\begin{array}{c}-0.4688^{* *} \\
{[-2.35]}\end{array}$ \\
\hline Lambda & $\begin{array}{c}2.3240^{* * * *} \\
{[2.80]}\end{array}$ & $\begin{array}{c}2.0254^{* * *} \\
{[2.74]}\end{array}$ & $\begin{array}{c}2.2498^{* * *} \\
{[2.90]}\end{array}$ & $\begin{array}{c}5.1202^{* * *} \\
{[3.04]}\end{array}$ & $\begin{array}{c}4.9825^{* * *} \\
{[3.39]}\end{array}$ & $\begin{array}{c}4.7752^{* * *} \\
{[3.10]}\end{array}$ \\
\hline 절편 & $\begin{array}{r}-11.2921 \\
{[-1.21]} \\
\end{array}$ & $\begin{array}{r}-9.1641 \\
{[-1.22]} \\
\end{array}$ & $\begin{array}{r}-10.1341 \\
{[-1.22]} \\
\end{array}$ & $\begin{array}{r}1.9680 \\
{[1.32]} \\
\end{array}$ & $\begin{array}{r}2.0880 \\
{[1.30]} \\
\end{array}$ & $\begin{array}{r}2.2540 \\
{[1.31]} \\
\end{array}$ \\
\hline 관측치 & 735 & 735 & 735 & 735 & 735 & 735 \\
\hline Uncensored obs. & 147 & 147 & 147 & 142 & 142 & 142 \\
\hline Wald test & 14.66 & 15.78 & 16.01 & 29.18 & 32.28 & 30.55 \\
\hline
\end{tabular}


Effect of IPO Underpricing on Seasoned Offerings

〈표 9〉 저가발행과 이후공모 규모 및 소요기간(계속)

Panel 3: OLS 추정결과-전체표본

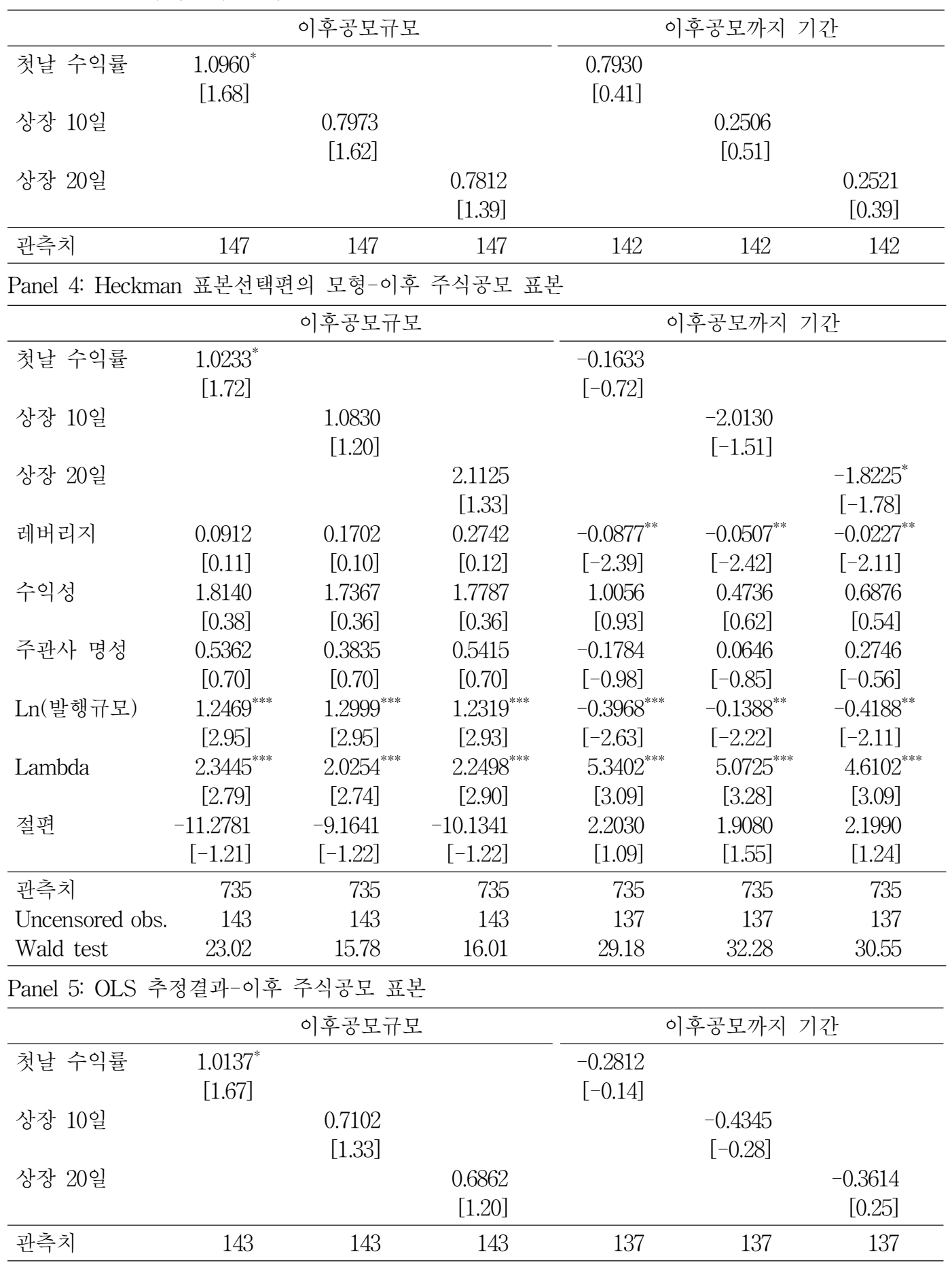

610 
한국증권학회지 제48권 5호 (2019)

더 짧은 것을 알 수 있다. Panel 2는 전체표본을 대상으로, Panel 3은 이후 주식공모만을 대상으로 분석한 Heckman 표본선택편의 모형의 추정결과이다. Lambda는 식 (3)과 같이 $1^{\text {st }}$ step에서 이후공모(또는 이후주식공모)의 여부에 대한 프로빗분석을 실시한 후 추정한 Inverse Mill's ratio이다. Lambda 값이 통계적으로 유의하게 나타났으므로 이후공모(또는 이후주식공모) 실시 여부는 내생성이 존재한다. Panel 3은 표본선택의 편의를 고려하지 않은 단순 OLS 회귀분석 결과이며, 주요 결과는 Panel 2와 동일하다.

Panel 2에서 첫날 수익률은 이후공모 규모에 $10 \%$ 유의수준에서 유의한 영향을 미치는 것으로 보이나 그 외의 저가발행 변수는 유의하지 않은 것으로 나타났다. 한편, IPO 발행규모가 큰 기업일수록 이후공모의 규모도 크게 나타났다. 종속변수가 이후공모까지 소요기간인 경우 상장 후 10일 동안 수익률만 약한 유의성(weak significance)을 갖는 것으로 보이고 나머지 저가발행 변수들은 이후공모까지 소요기간에 유의하지 않게 나타났다. 레버리지와 IPO 발행규모는 이후공모까지의 소요기간을 유의하게 줄이는 것으로 나타났다. 이후주식공모만을 대상으로 분석한 Panel 4의 결과도 Panel 2와 비슷하게 나타났다. 이후공모 규모의 결정요인을 분석한 결과 저가발행 변수들 중 첫날 수익률만 약한 유의성을 갖는 것으로 나타났으며, 상장 10 일 그리고 상장 20일 동안의 수익률은 유의하지 않게 나타났다. IPO 발행규모는 이후공모 규모와 유의한 정(+)의 관계를 갖는 것으로 나타났다. 또한 저가발행 변수들은 약한 유의성을 갖는 상장 20일 수익률을 제외하면 이후공모까지 기간에 유의한 영향을 미치지 않는 것으로 나타났다. 다만, 레버리지와 IPO 발행규모는 이후공모까지 소요기간을 유의하게 줄이는 것으로 나타났다. 결론적으로 본 회귀분석에서 저가발행이 이후공모 규모 또는 소요기간에 유의한 영향을 미친다는 증거는 발견되지 못하였다.

\section{4 추가 분석}

본 절에서는 강건성 분석의 일환으로 두 가지 추가분석을 실시하였다. 먼저 IPO 이후 수익률과 이후공모 실시여부에 따라 IPO 저가발행의 차이가 있는지를 살펴보았으며, IPO 이후 수익률에 따라 이후공모 여부에 차이가 있는지를 분석하였다. 이를 위하여 IPO 이후 6 개월 및 1 년의 보유초과수익률(BHAR, buy and hold abnormal returns)을 다음과 같이 산출하였다.

$$
B H A R_{i}=\prod_{t=1}^{N}\left(1+r_{i, t}\right)-\prod_{t=1}^{N}\left(1+r_{M, t}\right)
$$

위 식에서 $\prod_{t=1}^{N}\left(1+r_{i, t}\right)$ 은 IPO 이후 1 일부터 6 개월 또는 1 년 동안 기업 $\mathrm{i}$ 의 보유수익률이며, 시장지수의 보유수익률 $\left(\prod_{t=1}^{N}\left(1+r_{M, t}\right)\right)$ 을 차감하여 보유초과수익률 $\operatorname{BHAR}(6 \mathrm{~m})$ 와 $\operatorname{BHAR}(1 \mathrm{yr})$ 를 구하였다. 다음으로 BHAR의 크기를 기준으로 5 개의 포트폴리오를 구성하고, 이후공모의 여부에 따라 각 포트폴리오를 세분하여 총 10 개의 포트폴리오를 구축하였다. 각 포트폴리오의 IPO 저가발행률은 <표 $10>$ 과 같다.

<표 10>의 Panel 1에서 보면, IPO 이후 6개월 보유초과수익률로 구분한 집단 내에서 이후공모를 시행한 집단의 IPO 시 저가발행률의 평균이 월등히 높음을 알 수 있다. 또한 1년 
Effect of IPO Underpricing on Seasoned Offerings

보유초과수익률 크기에 따라 포트폴리오를 구성한 Panel 2에서도 이후공모 실시 집단의 저가 발행률이 높게 나타났다. 이는 IPO 기업의 자신의 내재가치 보다 낮은 가격으로 공모가를 책정하는 요인 중의 하나로 향후 원활한 추가 자본조달의 목적을 제시한 저가발행 신호이론이 주장하는 바와 사후적으로 일치하는 결과이다.

〈표 10〉IPO 이후 BHAR과 이후공모에 따른 저가발행률

Panel 1과 Panel 2는 각각 $\mathrm{BHAR}(6 \mathrm{~m})$ 와 $\mathrm{BHAR}(1 \mathrm{yr})$ 크기순으로 구성된 5 개의 $\mathrm{IPO}$ 집단의 이후공모 여부에 따른 저가발행률의 평균을 보여준다. 각 집단은 147 건의 $\mathrm{IPO}$ 로 구성되어 있으며, P1은 BHAR이 가장 높은 집단이고 $\mathrm{P} 5$ 는 $\mathrm{BHAR}$ 이 가장 낮은 집단이다.

Panel 1: BHAR(6m)와 이후공모 여부에 따른 저가발행률

\begin{tabular}{cccccc}
\hline & & & \multicolumn{3}{c}{ 저가발행률(평균) } \\
\cline { 2 - 4 } \cline { 5 - 6 } & 이후공모 여부 & & 첫날 수익률 & 상장 10 일 & 상장 20일 \\
\hline P1 & $\mathrm{SPO}=0$ & & 0.2600 & 0.2798 & 0.6600 \\
P2 & $\mathrm{SPO}=1$ & & 0.3077 & 0.4749 & 0.5644 \\
& $\mathrm{SPO}=0$ & 0.1195 & 0.1405 & 0.1458 \\
P3 & $\mathrm{SPO}=1$ & & 0.3583 & 0.2930 & 0.3028 \\
& $\mathrm{SPO}=0$ & 0.3174 & 0.3031 & 0.2680 \\
P4 & $\mathrm{SPO}=1$ & 0.4814 & 0.5250 & 0.4998 \\
& $\mathrm{SPO}=0$ & 0.5173 & 0.4190 & 0.3673 \\
P5 & $\mathrm{SPO}=1$ & 0.5856 & 0.5589 & 0.5411 \\
& $\mathrm{SPO}=0$ & 0.4823 & 0.2915 & 0.2180 \\
& $\mathrm{SPO}=1$ & 0.5203 & 0.3282 & 0.2773 \\
\hline
\end{tabular}

Panel 2: BHAR(1yr)와 이후공모 여부에 따른 저가발행률

\begin{tabular}{|c|c|c|c|c|}
\hline & & \multicolumn{3}{|c|}{ 저가발행률(평균) } \\
\hline & 이후공모 여부 & 첫날 수익률 & 상장 10 일 & 상장 20일 \\
\hline \multirow[t]{2}{*}{ P1 } & $\mathrm{SPO}=0$ & 0.2340 & 0.2214 & 0.2617 \\
\hline & $\mathrm{SPO}=1$ & 0.2167 & 0.3678 & 0.4560 \\
\hline \multirow[t]{2}{*}{ P2 } & $\mathrm{SPO}=0$ & 0.2317 & 0.2668 & 0.2428 \\
\hline & $\mathrm{SPO}=1$ & 0.3423 & 0.3854 & 0.4112 \\
\hline \multirow[t]{2}{*}{ P3 } & $\mathrm{SPO}=0$ & 0.2583 & 0.2055 & 0.2108 \\
\hline & $\mathrm{SPO}=1$ & 0.6700 & 0.5058 & 0.4681 \\
\hline \multirow[t]{2}{*}{ P4 } & $\mathrm{SPO}=0$ & 0.4535 & 0.3701 & 0.3102 \\
\hline & $\mathrm{SPO}=1$ & 0.4779 & 0.4543 & 0.4977 \\
\hline \multirow[t]{2}{*}{ P5 } & $\mathrm{SPO}=0$ & 0.5070 & 0.3549 & 0.3109 \\
\hline & $\mathrm{SPO}=1$ & 0.7268 & 0.9289 & 0.7616 \\
\hline
\end{tabular}

<표 11>은 IPO 이후 보유초과수익률에 따른 이후공모 또는 이후 주식공모 여부를 보여준다. 가장 높은 6개월(또는 1년) BHAR을 보인 P1집단의 $32 \%$ (또는 26\%) 기업이 이후공모를 실시하였으며, $12 \%$ (또는 $7 \%$ ) 기업이 이후 주식공모를 실시하였다. 가장 낮은 6 개월(또는 1년) $\mathrm{BHAR}$ 을 보인 P5집단에서는 8\%(또는 7\%) 기업이 이후공모를 실시하였으며, $1 \%$ 기업만이 이후 주식공모를 실시하였다. 이와 같은 결과는 IPO 이후 우량기업이 보다 적극적으로 이후공모를 실시한다는 본 연구의 가설과 일치하는 결과라고 할 수 있다. 
〈표 11〉IPO 이후 BHAR와 이후공모 및 이후 주식공모 여부

$\mathrm{BHAR}(6 \mathrm{~m})$ 와 $\mathrm{BHAR}(1 \mathrm{yr})$ 크기순으로 구성된 5개의 IPO 집단의 이후공모(또는 이후 주식공모) 확률, 즉 이후공모(또는 이후 주식공모) 건수 $\div$ 각 집단의 $\mathrm{IPO}$ 건수(147 건),을 보여준다. P1은 $\mathrm{BHAR}$ 이 가장 높은 집단이고 $\mathrm{P} 5$ 는 $\mathrm{BHAR}$ 이 가장 낮은 집단이다.

\begin{tabular}{lrrrrr}
\hline & $\mathrm{P} 1$ & $\mathrm{P} 2$ & $\mathrm{P} 3$ & $\mathrm{P} 4$ & $\mathrm{P} 5$ \\
\hline $\mathrm{BHAR}(6 \mathrm{~m})$ 기준 & & & & & \\
$\mathrm{SPO}=1$ & $32 \%$ & $13 \%$ & $23 \%$ & $12 \%$ & $8 \%$ \\
$\mathrm{SPO}$ Stock = 1 & $12 \%$ & $5 \%$ & $0 \%$ & $3 \%$ & $1 \%$ \\
\hline $\mathrm{BHAR}(1 \mathrm{yr})$ 기준 & & & & & \\
$\mathrm{SPO}=1$ & $26 \%$ & $25 \%$ & $16 \%$ & $15 \%$ & $7 \%$ \\
$\mathrm{SPO}$ & $7 \%$ & $7 \%$ & $3 \%$ & $2 \%$ & $1 \%$ \\
\hline
\end{tabular}

\section{5. 결론}

본 연구에서는 IPO 저가발행 원인에 대한 이론 중 저가발행 신호효과를 검증하기 위하여 2000년부터 2015년까지 코스닥 시장 IPO 870건을 대상으로 실증분석하였다. 저가발행률은 국내 주식시장의 가격제한폭제도를 고려하여 상장 첫날 수익률, 그리고 상장 이후 10 일, 20 일, 30 일 수익률 등으로 다양하게 정의하였다. 또한 IPO 이후 3년 동안 동일 기업에 의한 주식 및 채권공모를 이후공모로 정의하고 저가발행률이 이후공모 여부, 공모 규모 및 소요시간에 미치는 영향에 대하여 분석하였다.

실증분석 결과는 다음과 같다. 첫날 수익률은 이후공모 여부에 유의하지 않은 반면에 10 일 및 30일 수익률은 유의한 정(+)의 관계를 보였다. 이는 IPO 시 발행사가 저가발행을 함으로써 기업에 대한 투자자의 호감을 제고하여 추가 자본조달을 더욱 수월하게 한다는 가설과 일치하는 결과이다. 더욱이 이후공모를 시행한 기업은 IPO시 벤처캐피탈의 투자를 받을 뿐만 아니라 저가발행률도 높이는 경향이 있는데 이는 벤처캐피탈의 인증효과가 저가발행의 신호효과를 대체할 수 있다는 기존 연구와 다른 결과이다. 다음으로 저가발행이 이후공모 시 발행규모 및 소요기간 간 관계를 분석하였다. 회귀분석 결과 저가발행과 발행규모 및 소요기간 간 강한 유의적 관계는 나타나지 않았다.

기업의 이후공모 의사결정에 영향을 미치는 요인은 본 연구에서 고려한 IPO 저가발행 및 벤처캐피탈 지원 이외에 매우 다양하다. 주관사의 재지정 여부(Krigman et al., 2001), 공모 후 부채수용능력(Lemmon and Zender, 2010), 증자 직전 주식의 과대평가 여부(Baker and Wugler, 2002), 기업 생애주기 단계(DeAngelo et al., 2010) 등은 선행연구에서 알려진 주요 요인들이다. 또한 Kim et al.(2012) 및 Kim et al.(2015) 등은 원활한 이후공모를 위하여 발행기업이 회계적인 이익조정 또는 주식분할 등을 활용하여 투자자의 관심을 증폭시키는 기회주의적 재무정책을 사용한다고 하였다. 이러한 요인들을 실증분석 시 고려하지 못했다는 점은 본 연구의 한계라고 할 수 있다. 이러한 한계에도 불구하고 본 연구는 아직 국내에서 수행되지 않았던 IPO 저가발행의 신호효과에 대한 최초의 실증연구라는데 공헌점이 있다. 또한 저가발행이 이후공모 가능성을 높이는데 반하여 이후공모의 규모와 소요기간에는 유의한 영향을 미치지 않는다는 결과는 학문적 또는 실무적으로 시사하는 바가 크다고 할 수 있다. 
Effect of IPO Underpricing on Seasoned Offerings

\section{References}

Allen, F., and G. R. Faulhaber, 1989, Signaling by Underpricing in the IPO Market, Journal of Financial Economics, Vol. 23, pp. 303-323.

Baker, M., and J. Wurgler, 2002, Market Timing and Capital Structure, Journal of Finance, Vol. 57, 1-32.

Baron, D. P., and B. Holmström, 1980, The Investment Banking Contract for New Issues under Asymmetric Information: Delegation and the Incentive Problem, Journal of Finance, Vol. 35, pp. 1115-1138.

Belghitar, Y., and R. Dixon, 2012, Do Venture Capitalists Reduce Underpricing and Underperformance of IPOs? Applied Financial Economics, Vol. 22, pp. 33-44.

Benveniste, L. M., and P. A. Spindt, 1989, How Investment Bankers Determine the Offer Price and Allocation of New Issues, Journal of Financial Economics, Vol. 24, pp. 343-362.

Biais, B., P. Bossaerts, and J. C. Rochet, 2002, An Optimal IPO Mechanism, Review of Economic Studies, Vol. 69, pp. 117-146.

Booth, J. R., and R. Smith, 1986, Capital Raising, Underwriting and the Certification Hypothesis, Journal of Financial Economics, Vol. 15, pp. 261-281.

Byun, J. H., and S. S. Cho, 2011, IPO Lock-ups and Underpricing, Korean Journal of Financial Studies, Vol. 40, pp. 405-429.

Carter, R. B., and S. Manaster, 1990, Initial Public Offerings and Underwriter Reputation, Journal of Finance, Vol. 45, pp. 1045-1067.

Cornelli, F., and D. Goldreich, 2001, Bookbuilding and Strategic Allocation, Journal of Finance, Vol. 56, pp. 2337-2369.

Cornelli, F., and D. Goldreich, 2003, Bookbuilding: How Informative is the Order Book?, Journal of Finance, Vol. 58, pp. 1415-1443.

DeAngelo, H., L. DeAngelo, and R. M. Stulz, 2010, Seasoned Equity Offerings, Market Timing, and the Corporate Lifecycle, Journal of Financial Economics, Vol. 95, pp. 275-295.

Francis, B. B., I. Hasan, J. R. Lothian, and X. Sun, 2010, The Signaling Hypothesis Revisited: Evidence from Foreign IPOs, Journal of Financial and Quantitative Analysis, Vol. 45, pp. 81-106.

Grinblatt, M., and C. Y. Hwang, 1989, Signaling and the Pricing of New Issues, Journal of Finance, Vol. 44, pp. 393-420.

Heckman, J., 1976, The Common Structure of Statistical Models of Truncation, Sample Selection and Limited Dependent Variables and a Simple Estimator for Such Models, Annals of Economic and Social Measurement, Vol. 5, pp. 475-492. 
한국증권학회지 제48권 5호 (2019)

Heckman, J. J., 1979, Sample Bias as a Specification Error, Econometrica, Vol. 47, 153-161. Ibbotson, R. G., 1975, Price Performance of Common Stock New Issues, Journal of Financial Economics, Vol. 2, pp. 235-272.

Jang, S. W., and J. W. Khil, 2000, The Certification Role of Venture Capitalists in the KOSDAQ Market, Korean Journal of Financial Management, Vol. 17, pp. 111-136.

Jegadeesh, N., M. Weinstein, and I. Welch, 1993, An Empirical Investigation of IPO Returns and Subsequent Equity Offerings, Journal of Financial Economics, Vol. 34, pp. 153-175.

Kim, J. H., and S. H. Park, 2013, A Study on the Performance after IPO of Firms Financed by Venture Capital, Korean Journal of Accounting Research, Vol. 8, pp. 83-103.

Kim, K. S., J. Park, C. Y. Chung, and J. H. Lee, 2012, Is Stock Split a Manipulation Tool? Evidence from the Korean Stock Market, Asia-Pacific Journal of Financial Studies, Vol. 41, pp. 637-663.

Kim, K. S., J. H. Lee, and C. Y. Chung, 2015, Accrual Quality and Opportunistic Seasoned Equity Offering in the Korean Stock Market, Emerging Markets Finance and Trade, Vol. 51, pp. 140-157.

Kim, S., and S. Jun, 2017, Dark Side of Venture Capital Investment in IPOs, Korean Journal of Financial Studies, Vol. 46, pp. pp. 559-589.

Krigman, L., W. Shaw, and K. Womack, 2001, Why do Firms Switch Underwriters?, Journal of Financial Economics, Vol. 60, pp. 245-284.

Lee, J. Y., 2015, Effect of IPO Investor Protection on the Variability of IPO Initial Returns: Evidence from KOSDAQ, Korean Journal of Financial Studies, Vol. 44, pp. 577-594.

Lee, P., S. Taylor, and T. Walter, 1996, Australian IPO Pricing in the Short and Long Run, Journal of Banking and Finance, Vol. 20, pp. 1189-1210.

Lee, P. M., and S. Wahal, 2004, Grandstanding, Certification, and the Underpricing of Venture Capital Backed IPOs, Journal of Financial Economics, Vol. 73, pp. 375-407.

Lee, S. W., J. S. Kim, and D. J. Ryu, 2010, Venture Capitalist Certification in Initial Public Offerings: The Case of KOSDAQ Market, Korean Corporation Management Review, Vol. 17, pp. 1-22.

Lemmon, M. L., and J. F. Zender, 2010, Debt Capacity and Tests of Capital Structure Theories, Journal of Financial and Quantitative Analysis, Vol. 45, pp. 1161-1187.

Lim, B. K., P. S. Yoon, and S. H. Park, 2016, Analyst Informativeness and Investors' Trading Behavior: Focus on IPOs, Korean Journal of Financial Studies, Vol. 45, pp. 971-999.

Lin, T. H., 1996, The Certification Role of Large Block Shareholders in Initial Public Offerings: The Case of Venture Capitalists, Quarterly Journal of Business and Economics, Vol. 35, pp. 55-65.

Ljungqvist, A., Conflicts of Interest and Efficient Contracting in IPOs, Center for Law and 
Effect of IPO Underpricing on Seasoned Offerings

Business Research Paper, New York University, 2003.

Ljungqvist, A., IPO underpricing, Handbook of Corporate Finance: Empirical Corporate Finance, volume 1, 2007.

Ljungqvist, A., and W. J. Wilhelm, 2005, Does Prospect Theory Explain IPO Market Behavior?, Journal of Finance, Vol. 60, pp. 1759-1790.

Ljungqvist, A., V. Nanda, and R. Singh, 2006, Hot Markets, Investor Sentiment, and IPO Pricing, Journal of Business, Vol. 79, pp. 1667-1702.

Loughran, T., and J. R. Ritter, 2003, Why Has IPO Underpricing Increased Over Time?, Financial Management, Vol. 33, pp. 5-37.

Megginson, W., and K. A. Weiss, 1991, Venture Capitalist Certification in Initial Public Offerings, Journal of Finance, Vol. 46, pp. 879-903.

Michaely, R., and W. H. Shaw, 1994, The Pricing of Initial Public Offerings: Tests of Adverse-Selection and Signaling Theories, Review of Financial Studies, Vol. 7, pp. 279-319.

Oh, S. K., and H. H. Han, 2014, The Short- and Long-Term Performance of Venture-Backed IPO KOSDAQ Firms and the Roles of Venture Capitals in Korea, Asian Review of Financial Research, Vol. 27, pp. 457-491.

Park, K. J., and J. Q. Jeon, 2015, The Effect of IPO Syndicates on Underwriting Services: Focusing on Multiple Lead Underwriters and Co-Managers, Korean Journal of Financial Studies, Vol. 77, pp. 189-219

Rock, K., 1986, Why New Issues are Underpriced, Journal of Financial Economics, Vol. 15, pp. 187-212.

Slovin, M. B., M. E. Sushka, and Y. M. Bendeck, 1994, Seasoned Common Stock Issuance Following an IPO, Journal of Banking and Finance, Vol. 18, pp. 207-226.

Song, C. S., and Y. J. Lee, 2018, Certification Effect of Venture Capital on KOSDAQ IPO Firms, Korean Journal of Financial Management, Vol. 35, pp. 195-214.

Titman, S., and B. Trueman, 1986, Information Quality and the Valuation of New Issues, Journal of Accounting and Economics, Vol. 8, pp. 159-172.

Welch, I., 1989, Seasoned Offerings, Imitation Costs, and the Underpricing of Initial Public Offerings, Journal of Finance, Vol. 44, pp. 421-449.

Welch, I., 1996, Equity Offerings Following the IPO: Theory and Evidence, Journal of Corporate Finance, Vol. 2, pp. 227-259.

Wooldridge, J., Econometric Analysis of Cross Section and Panel Data, The MIT Press, 2002.

Yoon, P. S., 2016, The Announcement Effect of Seasoned Equity Offerings: A Re-examination, Korean Journal of Financial Studies, Vol. 45, pp. 379-415. 